\author{
Federico Marinelli
}




\title{
THE SHAREHOLDER VALUE AND DIVERSIFICATION PUZZLE
}

\author{
Federico Marinelli ${ }^{1}$
}

\begin{abstract}
Diversified firms are supposed to be valued less than the sum of their parts because of the diversification discount, but subsequent research questioned the causality of the discount. We analyze the relationship between diversification and shareholder value taking into consideration the persistence of profit over the long term. We offer new insights and a complementary view for investors: single-segment firms do not generate more shareholder value than diversified firms, and in some situations, the opposite is true. Moreover, we find that the relationship between diversification and shareholder value is not causal, but clearly depends on the firm's capacity to generate a long-term, persistently outstanding performance. Finally, we demonstrate that in comparison with diversified firms, single-segment firms might be considered "growth stocks" whose return is explained by higher volatility and a higher size premium.
\end{abstract}

Keywords: diversification, performance persistence, shareholder value, conditional variance.

NOTE: This research has been performed at IESE by Federico Marinelli (Former IESE Post Doc Research Fellow) under the supervision of Prof. José Manuel Campa.

\footnotetext{
${ }^{1}$ Colegio Universitario de Estudios Financieros (CUNEF), Madrid.
} 


\section{THE SHAREHOLDER VALUE AND DIVERSIFICATION PUZZLE}

The research domain that attempts to study the relationship between diversification and shareholder value has not yet reached definitive and interpretable findings to determine whether a diversification strategy creates or destroys value. Research by Lang and Stulz (1994) and Berger and Ofek (1995) shows unambiguously that the value of diversified firms is less than the sum of its parts. Hence, "on average," diversification is supposed to destroy value, and firms are better off if they remain focused on a single segment in order to maximize shareholder value. Subsequent research argues that this relationship is not causal: the discount is attributable to factors other than diversification per se (Campa and Kedia, 2002; Graham, Lemmon and Wolf, 2002; Villalonga, 2004a).

All research on the relationship between diversification and shareholder value attempts to answer the same research question: is a single-segment better off alone or within the conglomerate given the relaxation of financial constraints? This required the analysis to focus on explaining whether, on average, diversification destroys or creates value.

In this research, we do not attempt to answer the specific research question of whether, "on average," diversification is a poor strategy for shareholder value creation using the classical "chop-shop" approach. We based our analysis on one particular aspect of the critical empirical evidence available in industrial organisation economics and strategic management literature: the persistence of outstanding performance. This means that in the long term some firms perform better than other firms, independently of whether they are single-segment or diversified. We believe that looking for a diversification discount or premium would be an extremely relevant indicator if the firm's performance does not follow any specific pattern over time. But because of firms' long-term performance heterogeneity, finding an average indicator of a diversification discount or premium might become irrelevant when studying the relationship between diversification and shareholder value, given that over the long term, the firms that outperform are almost always the same, and the firms that underperform are almost always the same too.

Because of the long-term performance heterogeneity, our aim therefore in this research is to give an additional perspective on the relationship between diversification and shareholder value, looking at the tails of the distributions of both single-segment and diversified firms. This also suggests that this relationship is not causal and depends on the presence of firm-specific characteristics that lead some firms to generate more value from a diversification strategy than others. 
We use the same data and the same selection criteria used in the literature on the diversification discount, except that we limit the sample to single-segment and diversified firms with a minimum turnover of $\$ 500$ million in an attempt to separate the firm's return from the "size premium" asked for by investors (Fama and French, 1995).

First, we construct three performance indicators. Then we calculate the outstanding performance for each firm and for each year. An outstanding performance is considered to be a performance above its industry average.

Then we test the persistence of outstanding performance over time using various econometric techniques and the Markov conditional probabilities. As assumed, we found an important persistence in outstanding performance. We also notice that single-segment firms operate in industries with higher growth opportunities compared with diversified firms that seem to be considered "value stocks" by investors.

The persistence of performance heterogeneity over the long term suggests, for consistency reasons, that only single-segment firms and diversified firms belonging to the same "performer" class should be compared: top performers must be compared with top performers and bottom performers must be compared with bottom performers. This provides the opportunity to construct several portfolios composed of similar classes of the same performer type for both single-segment and diversified firms. Accordingly, we distributed both single-segment and diversified firms into quintiles, comparing with each other portfolios of top quintiles and portfolios of bottom quintiles. We also compare each type of firm (single-segment and diversified) in the top quintile portfolio with similar types of firms in the bottom quintile portfolio in order to gain additional empirical evidence of the persistence of outstanding performance over the long term.

Comparing single-segment and diversified firms using portfolios of firms with similar performance characteristics allows us a) to study the relationship between diversification and shareholder value from a new perspective, and b) use several techniques in order to measure and explain the firm's return and risk. To measure shareholder value, we calculate the market return and Jensen's alpha for each year and for each portfolio. When we compare the top quintiles, we find that single-segment firms show a statistically significant higher performance only during two years but have a higher unconditional risk during the entire time series (1999 2006). For the remaining time series, both portfolios show similar returns, but the portfolio of single-segment firms indicates a higher unconditional risk. On the other hand, when we perform the same analysis for the portfolio of the bottom quintiles, diversified firms clearly outperform, with a higher return and a lower unconditional risk than single-segment firms. We obtain similar conclusions when we compare the results obtained for Jensen's alpha. We can clearly conclude that from an investor's viewpoint, diversified firms do not destroy value compared with single-segment firms. Moreover, this empirical evidence becomes very strong when we compare the portfolio of the top quintile of diversified firms with the portfolio of the bottom quintile of single-segment firms: any "expected" diversification discount is not justified.

Basic statistics indicate that single-segment and diversified firms are different in size and operate in different sectors. These differences are certainly included in the return expected by investors. Hence, we regress the portfolios of top and bottom quintiles against Fama and French's assets pricing model. We find that the size premium is higher within single-segment firms, while diversified firms appear to be "value stocks," in comparison with single-segment firms, which appear to be "growth stocks." 
Finally, we further investigate the volatility of the portfolios of single-segment and diversified firms, using the daily conditional variance and covariance for each portfolio. We find that, independently of the performance group (top or bottom quintiles), single-segment firms show a higher volatility, explained by a higher long-term volatility or "sticky" volatility, and also a higher degree of reaction to innovation or latest market news. As expected, we find that volatility is higher in the bottom quintiles than in the top quintiles.

This rest of the paper is organized as follows. In the next session we briefly discuss related literature. Section III describes the data and the sample selection. Section IV describes how we calculate the outstanding performance, shows the preliminary results, and finally tests the persistence of performance heterogeneity among diversified firms using different econometrics techniques and the Markov conditional probabilities. Section V calculates and compares top performers and bottom performers among both single-segment and diversified firms according to the following indicators: a) the shareholder value in terms of return and unconditional risk; b) Jensen's alpha; c) Fama and French's three-factor model, and d) the conditional variance and covariance. Within each section, the findings are discussed. Finally, Section VI concludes.

\section{Review of the Literature}

The research domain that attempts to study the relationship between diversification and performance has not yet reached definitive and interpretable findings to determine whether a diversification strategy creates or destroys value. Gains from diversification come from economies of scales (Chandler, 1977) or from increased debt capacity (Lewellen, 1971) or from exploitation of firm-specific assets in several businesses (Wernerfelt and Montgomery, 1988).

Business segments within a conglomerate are supposed to benefit from the internal capital market; the headquarters is considered an effective financial intermediary through "winner picking" behavior (Williamson, 1975; Stein, 1997): the business segment benefits from higher rights control over projects, allowing better information flow, higher assets redeployment, and relaxation of credit constraints (Gertner, Sharfstein, and Stein, 1994). These benefits are supposed to offset the internal capital market flip-side, identified as the reduction of manager entrepreneurial incentive, the effort dilution factor and agency argumentation of on-the-job consumption (Jensen, 1986), in which projects receive a lower level of funding than they could obtain standing alone because of crosssubsidisation, in which high-performing divisions subsidise poor-performing divisions, destroying shareholder value (Lang and Stulz, 1994; Berg and Ofek, 1995; Denis, Denis, and Sarin, 1997; Rajan, Servaes, and Zingales 2000; Sharfstein and Stein, 2000).

Lang and Stulz (1994), using an industry-adjusted Tobin's $q$, and Berg and Ofek (1995) using an excess value methodology, attempt to answer the research question: is a business segment better off alone or within a conglomerate? This implies looking for an average measurement of premium or discount related to the decision to diversify.

They find that the value of the diversified firms is, "on average," less than that of a comparable portfolio of specialized firms. The diversification discount is explained by the inefficiency of the internal capital market: the corporate headquarters does not channel funds to the segments that have the best business opportunities. They conclude unambiguously that diversification is not a successful path to higher performance because the value of the diversified firm is less than the sum of its parts by an average discount factor of 13-15\% (Berg and Ofek, 1995). 
This method of portfolios of specialized firms or "pure play firms" (Lang and Stulz, 1994; Berg and Ofek, 1995) suffers from a number of drawbacks: as sample selection (Campa \& Kedia, 2002; Villalonga, 2004a), measurement errors, and data artefact related to the construction of the excess value methodology (Graham, Lemmon, and Wolf, 2002; Schoar, 2002; Mansi and Reeb, 2002; Villalonga, 2004b; Emms \& Kale, 2006; Stowe and Xing, 2006). Once these biases are corrected, the diversification discount becomes very small or even turns into a premium. Campa and Kedia (2002) and Villalonga (2004a) find that the diversification discount was explained by endogeneity (diversifying firms are poor performers prior to diversification). According to these authors, the relationship between the decision to diversify and firm value is not causal, and it depends on the firm's characteristics: once this bias is corrected, the empirical evidence showed that the decision to diversify is a value-enhancing strategy. A key fundamental empirical evidence in industrial organization economics and strategic management literature is the existence of persistence of superior performance, defined as a statistically significant above-average performance relative to a reference set (such as an industry) that persists over the long-term (Mueller, 1977; Jacobsen, 1988; Schohl, 1990; Waring, 1996; McGahan and Porter, 1999, 2003; Maruyama and Odagiri, 2002; Wiggins and Ruefli, 2002, 2005; Yurtoglu, 2004; Bentzen, Strojer Madsen, Valdemart, and Dilling-Hansen, 2005; Kaplan and Schoar, 2005; Marinelli, 2008). If the competitive advantage (from a specific position in the industry or because of strategic assets) had been sustainable only in the short term, it would have triggered a serious reconsideration especially in the field of strategic management science. The persistence in firms' performance is therefore a fundamental characteristic to be taken into consideration when studying whether a firm's diversification destroys value compared with firms that remain focused on a single business.

\section{Data and Sample Selection Criteria}

The new segment reporting standard SFAS 131 was issued by the Financial Accounting Standards Boards (FASB) in June 1997 and is effective for fiscal years commencing after December 15, 1997. According to the SFAS 131, a firm must report disaggregated information by business line. In addition, the information provided under the new standard about segment definition would be less subjective than what was provided under the previous SFAS 14 and it induces companies to disclose their diversification and fund transfer strategies, thereby reflecting any underlying agency problem (Berger and Hann, 2003). Previous studies of the diversification discount have fixed a lower limit of \$20 million in turnover (Berger and Ofek, 1995; Campa and Kedia, 2002) or \$100 million in assets on average (Lang and Stulz, 1994) in order to be included in the sample. This implies that the empirical findings from these studies do not control for the "size premium" historically received by investors who invest in the stocks of companies with a relatively small market capitalisation: small stocks tend to be less profitable than large stocks. It was noticed during the 1981-1982 recession that small stocks showed a prolonged earning depression and were not able to participate in the boom of the middle and late 1980's. This led to a size-related risk factor for small capitalized firms (Fama and French, 1995). Because size directly influences stock returns, we attempt to control for the "size effect" by introducing a lower limit of $\$ 500$ million in turnover in the sample selection and removing from the sample all firms that are below this threshold. Compared with previous studies of the diversification discount, this choice reduces the sample size but it also allows us to attempt to moderate the size premium's effects on stock returns when we compare diversified and single-segment firms. A sample of 611 diversified and single-segment firms with turnovers 
higher than $\$ 500$ million was taken from Compustat Industry Segment (CIS) during the period 1999-2006.

Within the sample, 317 firms are diversified firms, representing 42\% of the population of diversified firms with a turnover higher than $\$ 500$ million during the time series 1999-2006 and 294 are single-segment firms representing 69.5\% of the population of single-segment firms with a turnover higher than $\$ 500$ million during the time series 1999-2006. Because our research is based on the empirical evidence of the persistence of "abnormal returns" within both forms of firms (single-segment and diversified), we collect data only from firms that remain single-segment or remain diversified during the entire time series. In addition, testing the persistence of abnormal returns requires balanced panel data; thus, firms missing one or more years of data cannot be included in the sample. Although we had to exclude a certain number of firms, we were able to obtain $42 \%$ of the population of diversified firms and $69.5 \%$ of the population of single-segment firms, which allowed us to generalize our findings to the entire population of diversified and single-segment firms. With this study method, we have introduced a survival bias in our sample (i.e. diversified firms that refocus to improve performance and single-segment firms that diversify are not taken into consideration).

The length of this time series ( 8 years) is justified by the aim of the research question: to compare diversified and single-segment firms that remained diversified and single-segment, respectively, during the entire time period. A longer time series, e.g. 15-20 years, as used in the previous literature on diversification, may increase the self-selection bias effect, especially for diversified firms, given that poor-performing diversified firms may choose to refocus on one business in order to improve performance (Wernerfelt and Montgomery, 1988), leaving only high-performing diversified firms in the sample. Moreover, the requirement related to balanced panel data shortens the time series: a longer time series would have caused difficulties in generalising our empirical findings as it would have led to more companies being excluded because of missing data.

To enable a comparison with previous studies in finance, firms belonging to agriculture (SIC 100-900), regulated industries (SIC 4900-4999), financial services (SIC 6000-6900), depositary receipts (SIC 8888), international affairs (SIC 9721), and non-operating establishments (SIC 9995), are excluded. Diversified firms may not fully allocate accounting items in their reported business segments. This lack of consistency in reporting may lead to problems with the use of business segment data. Therefore, we have adopted Berger and Ofek's (1995) convention of requiring that the sum of segment sales (assets) be within 1\% (25\%) of the consolidated firm total reported in Compustat. For those firms that meet this criterion, any unallocated assets are explicitly allocated to it; for example, if a firm's assets level is 10\% smaller (larger) than the sum of the segment assets, each segment's assets are reduced (increased) by $10 \%$. Moreover, the corporate segment data (sales, assets, capital expenditure, operating income and depreciation) are allocated to the segments on an asset-weighted basis. These adjustments should mitigate the shortcomings highlighted by Berger and Hann (2003) in the use of SFAS 131. Because the excess value methodology is not used, as opposed to the literature on finance, firms that have segments in the financial industry or in a regulated industry are not excluded but instead just that particular segment is excluded from the analysis. Around 25 firms in the sample have activities in the financial industry. This financial segment is represented by leasing activities and, given the interest spread between diversified firms' cost of debt and the final lending interest, it is assumed that this activity is profitable. Hence, excluding these types of firms may introduce a bias in the sample selection given that diversified firms enjoy greater debt capacity, 
lower cost of debt, and debt tax shield relative to single-segment firms due to lower risk (Lewellen, 1971; Mansi and Reeb, 2002).

\section{Identification of Performance Measurements and Test of Persistence of Outstanding Performance}

\section{A: Variables}

In order to compare performance of firms with segments in different industries with different industry-specific levels of financial performance, the performance indicator used here is the outstanding performance (outstanding with the meaning of performance above the industry average calculated using data from single-segment and diversified firms). For diversified firms, the firm whose sum of the asset-weighted averages of the performance of its segments relative to the industry average is positive is considered outstanding. For single-segment firms, its performance is compared with the average performance of its industry segment. There are three performance indicators: OROA, OSALES/ASSETS, and OOP/SALES, that measure performance in the return on assets, operating profits/sales and return on sales relative to industry averages, respectively. We construct the following indicators of outstanding performance:

$$
\text { (i) } \mathrm{OROA}_{i t}=\sum_{i=1}^{n}\left(R O A_{j i t}-R O A_{\text {indjt }}\right)\left(\frac{A_{j i t}}{A_{i t}}\right)
$$

where $\mathrm{ROA}_{\mathrm{jit}}$ represents the ROA of the industry $j$ defined by a 6-digit NAICS code of the segment of firm $i$ during period $t$ and $\mathrm{ROA}_{\text {indjt }}$ represents the asset-weighted average ROA of the same industry $j$ during period $t . \mathrm{A}_{\mathrm{jit}} / \mathrm{A}_{\mathrm{it}}$ represents the portion of the assets of segment $j$ within firm $i$ during period $t$. In order to calculate a consistent benchmark $\mathrm{ROA}_{\text {indjt }}$, following the previous literature on finance for the calculation of the excess value methodology (Berg and Ofek, 1995), at least 5 segments are required with the same industry defined by a 6-digit NAICS code. If this condition is not fulfilled, the industry is then defined by a 5-digit NAICS code and then by a 4-digit NAICS code until this condition is fulfilled.

The other two indicators of outstanding performance - the sales/assets ratio and the operating profit/sales (ROS) ratio - are constructed applying the same logic as $\mathrm{OROA}_{\mathrm{it}}$ :

$$
\text { (ii) OSALES/ASSETS } i t=\sum_{i=1}^{n}\left(\frac{S A L E S_{j i t}}{A S S E T S_{j i t}}-\frac{S A L E S_{i n d j t}}{A S S E T S_{i n d j t}}\right)\left(\frac{A_{j i t}}{A_{i t}}\right)
$$

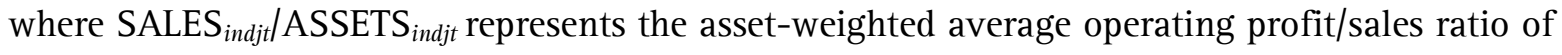
the same industry $j$ during period $t$.

$$
\text { (iii) } O R O S_{i t}=\sum_{i=1}^{n}\left(\operatorname{ROS}_{j i t}-\operatorname{ROS}_{i n d j t}\right)\left(\frac{A_{j i t}}{A_{i t}}\right)
$$

where ROS indjt represents the asset-weighted average ROS ratio of the same industry $\mathrm{j}$ during period t. 
Table 1 summarises the descriptive statistics of the three outstanding performance indicators of both diversified and single-segment firms. On average, diversified firms slightly underperform their industry sectors for all three indicators of outstanding performance compared with singlesegment firms. However, diversified firms seem to have higher average outstanding ROA but lower outstanding SALES/ASSETS (OSALES/ASSETS). Table II shows the 15 main industries (the 15 most frequent industry segments) for both diversified and single-segment firms. Diversified firms seem more concentrated in manufacturing segments (NAICS code 31-33) with moderate growth opportunities (average ME/BE, 2.58 and 2.64) while single-segment firms seem to be focused on manufacturing segments, wholesale trade and retail segments (NAICS 42 and 44-45) with higher growth opportunities (average ME/BE, 2.75 and 2.84). When both types of firms are compared, it can be concluded that diversified firms seem to operate in more mature industries while single-segment firms operate in growth industries. 


\section{Table 1}

Descriptive statistics of performance indicators within single-segment and diversified firms

Three measures of outstanding performance are developed: outstanding ROA (OROA), outstanding SALES/ASSETS and outstanding Operating Profit/Sales (OROS). They enable the performance of single-segment and diversified firms in different industries to be compared, assessing whether the firm performs below or above their industry average. Here, the average ROA and the average assets were also calculated for the entire sample of single-segment and diversified firm as a measurement of the firms' size. The industry average ROA, SALES/ASSETS, and ROS indicators correspond to the equal-weighted average of the industries in which the single-segment and diversified firms operate.

\begin{tabular}{|c|c|c|c|c|c|c|c|c|c|c|}
\hline & \multicolumn{5}{|c|}{ Diversified firms } & \multicolumn{5}{|c|}{ Single-segment firms } \\
\hline & Mean & Med & $\sigma$ & Max. & Min. & Mean & Med & $\sigma$ & Max. & Min. \\
\hline Assets & 8,225 & 1,905 & 21,526 & 265,680 & 79 & 4,365 & 1,721 & 6,875 & 63,387 & 140 \\
\hline Firm's ROA & 0.10 & 0.09 & 0.09 & 1.43 & -0.55 & 0.11 & 0.10 & 0.08 & 0.46 & -0.40 \\
\hline Outstanding ROA (ROA) & -0.01 & -0.01 & 0.08 & 0.73 & -0.95 & 0.00 & 0.00 & 0.08 & 0.66 & -0.36 \\
\hline Outstanding SALES/ASSETS & -0.03 & -0.09 & 0.87 & 20.12 & -4.62 & 0.07 & -0.01 & 0.81 & 12.35 & -3.66 \\
\hline Outstanding ROS (OROS) & -0.01 & 0.00 & 0.43 & 3.89 & -16.84 & 0.01 & 0.00 & 0.29 & 6.71 & -1.32 \\
\hline Industry ROA & 0.11 & 0.10 & 0.09 & 1.42 & -0.70 & 0.10 & 0.10 & 0.07 & 0.34 & -0.70 \\
\hline Industry SALES/ASSETS & 1.29 & 1.12 & 0.80 & 14.54 & 0.09 & 1.40 & 1.24 & 0.87 & 5.40 & 0.15 \\
\hline Industry ROS & 0.10 & 0.09 & 0.25 & 5.49 & -6.67 & 0.10 & 0.08 & 0.30 & 1.12 & -6.67 \\
\hline
\end{tabular}

8 - IESE Business School-University of Navarra 


\section{Table II}

Descriptive statistics for the 15 most frequent industry sectors (business segments) of single-segment and diversified firms

This table shows the ranking, description and percentage out of the total of the 15 most frequent industry sectors of diversified firms and singlesegment firms that represent 34.5\% and 43\%, respectively, of the total number of industries (business segments) during the times series $1999-2006$. Using the NAICS codes to SIC codes correspondence table, it is possible to allocate each of the 15 most frequent business segments of our sample to one of the 48 industry sectors identified by Fama and French. This allow us to obtain the following estimates for the 15 most frequent industry sectors: a) the average industry return - value-weighted industry portfolio; b) the average industry return - equal-weighted industry portfolio; c) the industry average $\mathrm{ME} / \mathrm{BE}$ - value-weighted industry portfolio, and d) the industry average $\mathrm{ME} / \mathrm{BE}$ - equal-weighted industry portfolio.

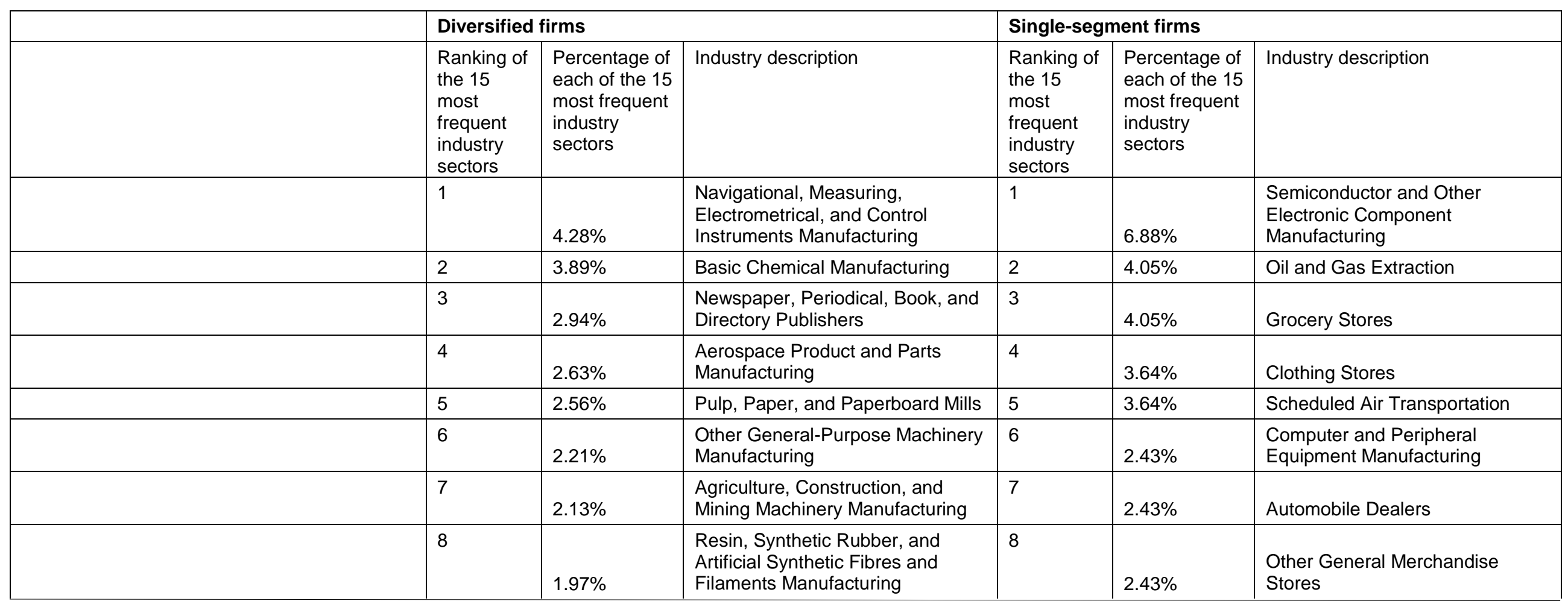




\section{Table II (continued)}

\begin{tabular}{|c|c|c|c|c|c|c|}
\hline & 9 & $1.89 \%$ & Motor Vehicle Parts Manufacturing & 9 & $2.02 \%$ & Beverage Manufacturing \\
\hline & 10 & $1.86 \%$ & Support Activities for Mining & 10 & $2.02 \%$ & $\begin{array}{l}\text { Motor Vehicle Parts } \\
\text { Manufacturing }\end{array}$ \\
\hline & 11 & $1.80 \%$ & Plastic Product Manufacturing & 11 & $2.02 \%$ & $\begin{array}{l}\text { Electrical and Electronic Goods } \\
\text { Merchant Wholesalers }\end{array}$ \\
\hline & 12 & $1.61 \%$ & $\begin{array}{l}\text { Communication Equipment } \\
\text { Manufacturing }\end{array}$ & 12 & $2.02 \%$ & Department Stores \\
\hline & 13 & $1.61 \%$ & $\begin{array}{l}\text { Non-ferrous Metal (except } \\
\text { Aluminium) Production and } \\
\text { Processing }\end{array}$ & 13 & $2.02 \%$ & Full-Service Restaurants \\
\hline & 14 & $1.58 \%$ & $\begin{array}{l}\text { Radio and Television } \\
\text { Broadcasting }\end{array}$ & 14 & $1.62 \%$ & $\begin{array}{l}\text { Pharmaceutical and Medicine } \\
\text { Manufacturing }\end{array}$ \\
\hline & 15 & $1.47 \%$ & $\begin{array}{l}\text { Pharmaceutical and Medicine } \\
\text { Manufacturing }\end{array}$ & 15 & $1.62 \%$ & $\begin{array}{l}\text { Household and Institutional } \\
\text { Furniture and Kitchen Cabinet } \\
\text { Manufacturing }\end{array}$ \\
\hline $\begin{array}{l}\text { Industry average return - value-weighted } \\
\text { industry portfolio }\end{array}$ & \multicolumn{3}{|l|}{0.0813} & \multicolumn{3}{|l|}{0.0630} \\
\hline $\begin{array}{l}\text { Industry average return - equal-weighted } \\
\text { industry portfolio }\end{array}$ & \multicolumn{3}{|l|}{0.2888} & \multicolumn{3}{|l|}{0.2854} \\
\hline $\begin{array}{l}\text { Industry average ME/BE - value-weighted } \\
\text { industry portfolio }\end{array}$ & \multicolumn{3}{|l|}{2.58} & \multicolumn{3}{|l|}{2.75} \\
\hline $\begin{array}{l}\text { Industry average ME/BE - equal-weighted } \\
\text { industry portfolio }\end{array}$ & \multicolumn{3}{|l|}{2.64} & \multicolumn{3}{|l|}{2.84} \\
\hline
\end{tabular}




\section{B: Test of persistent performance}

To test persistence in performance, first we used an autoregressive model AR (1) such as:

$$
Y_{i t}=\alpha+\beta Y_{i(t-1)}+\left(\eta_{i}+v_{i t}\right)
$$

The test was carried out using several econometric techniques. $\mathrm{Y}_{\mathrm{it}}$ is the observation of the performance indicators of firm $i$ in period $t, \mathrm{Y}_{\mathrm{i}(t-1)}$ is the performance of the previous period, $\eta_{\mathrm{i}}$ is the stochastic unobserved firm-specific time-invariant effect, $v_{\text {it }}$ is the error component and $\alpha$ is the constant term. The value of $\beta$ is estimated using different econometric measurements and the Hausman test (null hypothesis $\mathrm{E}\left[\mathrm{Y}_{\mathrm{it}} \eta_{\mathrm{i}}\right]=0$ ) is performed. 


\section{Table III}

Autoregressive model AR(1) of persistence of outstanding performance

To test the persistence of outstanding performance, an autoregressive model AR(1) such as: $Y_{i t}=\alpha+\beta Y_{i(t-1)}+\left(\eta_{i}+v_{i t}\right)$ is used to determine, applying various econometric techniques, the value of the autoregressive coefficient $\beta$ : pooled OLS, Within-Group and the instrumental variables (IV) 2SLS. To select the most efficient econometric model, the Hausman test (null hypothesis $\mathrm{E}\left[\mathrm{Y}_{i t} \eta_{i}\right]=0$ ) is used to assess the presence of firm's time-invariant specific effect $\eta_{i}$. The Hausman test indicates whether the Pooled OLS provides a consistent estimate of $\beta$.

\begin{tabular}{|c|c|c|c|c|c|c|c|c|c|}
\hline & \multicolumn{3}{|l|}{ Entire sample } & \multicolumn{3}{|c|}{ Single-segment firms } & \multicolumn{3}{|c|}{ Diversified firms } \\
\hline & Pooled OLS & Within-group & IV 2SLS & Pooled OLS & Within-group & IV 2SLS & Pooled OLS & Within-group & IV 2SLS \\
\hline $\begin{array}{l}\text { Outstanding } \\
\text { ROA }\end{array}$ & $\begin{array}{l}0.697 \\
(27.72)\end{array}$ & $\begin{array}{l}0.248 \\
(6.63)\end{array}$ & $\begin{array}{l}0.352 \\
(5.38)\end{array}$ & $\begin{array}{l}0.692 \\
(17.51)\end{array}$ & $\begin{array}{l}0.3126 \\
(5.55)\end{array}$ & $\begin{array}{l}0.5207 \\
(4.93)\end{array}$ & $\begin{array}{l}0.6973 \\
(20.96)\end{array}$ & $\begin{array}{l}0.2115 \\
(5.73)\end{array}$ & $\begin{array}{l}0.2104 \\
(3.62)\end{array}$ \\
\hline Adjusted $\mathrm{R}^{2}$ & 0.48 & 0.47 & & 0.49 & 0.48 & & 0.48 & 0.4553 & \\
\hline Hausman test & \multicolumn{3}{|l|}{$x^{2}=175.52$} & \multicolumn{3}{|l|}{$x^{2}=20.12$} & \multicolumn{3}{|l|}{$x^{2}=310.20$} \\
\hline $\begin{array}{l}\text { Outstanding } \\
\text { SALES/ASSETS }\end{array}$ & $\begin{array}{l}0.799 \\
(19.25)\end{array}$ & $\begin{array}{l}0.450 \\
(5.53)\end{array}$ & $\begin{array}{l}0.681 \\
(3.46)\end{array}$ & $\begin{array}{l}0.7753 \\
(14.93)\end{array}$ & $\begin{array}{l}0.5282 \\
(6.40)\end{array}$ & $\begin{array}{l}0.6579 \\
(3.58)\end{array}$ & $\begin{array}{l}0.8112 \\
(26.21)\end{array}$ & $\begin{array}{l}0.4281 \\
(4.06)\end{array}$ & $\begin{array}{l}0.8461 \\
(2.72)\end{array}$ \\
\hline Adjusted $\mathrm{R}^{2}$ & 0.70 & 0.70 & & 0.682 & 0.681 & & 0.7661 & 0.1967 & \\
\hline Hausman test & \multicolumn{3}{|l|}{$x^{2}=7.36$} & \multicolumn{3}{|l|}{$x^{2}=0.85$} & \multicolumn{3}{|l|}{$x^{2}=51.83$} \\
\hline $\begin{array}{l}\text { Outstanding } \\
\text { ROS }\end{array}$ & $\begin{array}{l}0.383 \\
(5.01)\end{array}$ & $\begin{array}{l}0.109 \\
(2.81)\end{array}$ & 0.427 & $\begin{array}{l}0.6714 \\
(25.07)\end{array}$ & $\begin{array}{l}0.3612 \\
(7.20)\end{array}$ & $\begin{array}{l}1.042 \\
(5.79)\end{array}$ & $\begin{array}{l}0.3045 \\
(9.91)\end{array}$ & $\begin{array}{l}0.0564 \\
(3.17)\end{array}$ & $\begin{array}{l}0.2213 \\
(2.07)\end{array}$ \\
\hline Adjusted $\mathrm{R}^{2}$ & 0.15 & 0.13 & & 0.511 & 0.5078 & & 0.0913 & 0.0568 & \\
\hline Hausman test & \multicolumn{3}{|l|}{$x^{2}=0.57$} & \multicolumn{3}{|l|}{$x^{2}=0.58$} & \multicolumn{3}{|l|}{$x^{2}=19.78$} \\
\hline
\end{tabular}


Table III shows that all the autoregressive models AR(1) give a consistent positive value of $\beta$ that confirms the hypothesis of a persistent performance for all three performance indicators. The Hausman test shows stochastic unobserved firm-specific time-invariant effects $\left(\eta_{i}\right)$ for diversified firms, while $\eta_{i}$ is only present for the outstanding ROA (OROA) indicator for singlesegment firms. As suggested by Bond (2002) and Arellano (2003), AR(1) through pooled OLS is inconsistent and biased upwards since the explanatory variable $Y_{i t-1}$ is positively correlated with the error term $\left(\eta_{i}+v_{i t}\right)$ due to the presence of the firm time-invariant specific effect $\eta_{i}$. The Within-Group estimator eliminates the sources of inconsistency by transforming the equation to eliminate the firm time-invariant specific effect $\eta_{i}$. However, this transformation introduces a negative correlation of order $1 /(\mathrm{t}-1)$ between the transformed lagged dependent variables and the transformed error term, suggesting that, except for time series with $t$ greater than or equal to 15 (Arellano, 2003), the Within-Group estimator is biased downwards and therefore is not efficient. The correlation between $\mathrm{Y}_{i t}$ and $\eta_{i}$ indicates that the consistent estimation of $\beta$ is represented only by model 3 through the autoregressive first difference Two-Stage Least Squared (2SLS) developed by Anderson and Hsiao (1981) in which the firm-specific effects are eliminated hence the estimator is consistent. For the entire sample and for both single-segment and diversified firms, we find strong empirical evidence of a persistence in outstanding performance between time $t$ and time $t-1$.

\section{Composition of single-segment and diversified firm classes}

The value of the autoregressive coefficient $\beta$ confirms the existence of a persistent outstanding performance. Due to this empirical evidence, we operate as follows to compare the difference in shareholder value between diversified and single-segment firms: firms are ranked according to their outstanding performance indicators for every year, classes of quintiles are formed and the Markov conditional probability of remaining in the same quintile from time $t$ to $t+1$ during the times series 1999-2006 is calculated. The null hypothesis (absence of persistent outstanding performance) would assume that the value for remaining in the same quintile or migrating to one of the other quintiles would have been close to 20\%. Our results show a persistently outstanding performance for all three indicators. 


\section{Table IV}

\section{Markov conditional probabilities}

An additional measurement of the persistence of outstanding performance is the conditional Markov probabilities. For all indicators of outstanding performance, and during each year of the time series 1999-2006, all single-segment and diversified firms are sorted into performance quintiles and the Markov conditional probability that indicates that a firm will either stay in the same performance quintile, or move into one of the other four quintiles in the following year $(t+1)$ is determined. For the hypothesis $\mathrm{H}_{0}$ (absence of persistence of outstanding performance), the Markov conditional probabilities would have been around 20\%, which indicates that at time $(t+1)$ a firm has the same probability of staying in the same quintile as it does of moving into one of the lower or upper quintiles. For the hypothesis $\mathrm{H}_{1}$ (existence of a persistence of outstanding performance between time $t$ and time $t+1$ ), the value of the Markov conditional probability would be different from 20\%.

\begin{tabular}{|c|c|c|c|c|c|c|c|c|c|c|c|}
\hline \multicolumn{6}{|c|}{ Diversified Firms } & \multicolumn{6}{|c|}{ Single-segment firms } \\
\hline \multicolumn{12}{|c|}{ Outstanding ROA (OROA) } \\
\hline & $\begin{array}{c}\text { Top Quintile } \\
(\%)\end{array}$ & $\begin{array}{c}\text { II Quintile } \\
(\%)\end{array}$ & $\begin{array}{c}\text { III Quintile } \\
(\%)\end{array}$ & $\begin{array}{c}\text { IV Quintile } \\
(\%)\end{array}$ & $\begin{array}{c}\text { Bottom } \\
\text { Quintile (\%) }\end{array}$ & & $\begin{array}{c}\begin{array}{c}\text { Top Quintile } \\
(\%)\end{array} \\
\end{array}$ & $\begin{array}{c}\text { II Quintile } \\
(\%)\end{array}$ & $\begin{array}{c}\text { III Quintile } \\
(\%)\end{array}$ & $\begin{array}{c}\text { IV Quintile } \\
(\%)\end{array}$ & $\begin{array}{c}\text { Bottom } \\
\text { Quintile (\%) }\end{array}$ \\
\hline Top Quintile & 63 & 20 & 8 & 3 & 5 & Top Quintile & 62 & 22 & 8 & 5 & 3 \\
\hline II Quintile & 21 & 40 & 23 & 10 & 6 & II Quintile & 22 & 44 & 22 & 7 & 5 \\
\hline III Quintile & 8 & 26 & 32 & 23 & 10 & III Quintile & 8 & 20 & 38 & 27 & 8 \\
\hline IV Quintile & 3 & 9 & 26 & 40 & 22 & IV Quintile & 4 & 9 & 25 & 38 & 24 \\
\hline $\begin{array}{l}\text { Bottom } \\
\text { Quintile }\end{array}$ & 4 & 5 & 12 & 26 & 52 & $\begin{array}{l}\text { Bottom } \\
\text { Quintile }\end{array}$ & 4 & 5 & 8 & 23 & 59 \\
\hline \multicolumn{12}{|c|}{ Outstanding OSALES/ASSETS } \\
\hline & $\begin{array}{c}\text { Top Quintile } \\
(\%)\end{array}$ & $\begin{array}{c}\text { II Quintile } \\
(\%)\end{array}$ & $\begin{array}{c}\text { III Quintile } \\
(\%)\end{array}$ & $\begin{array}{c}\text { IV Quintile } \\
(\%)\end{array}$ & $\begin{array}{c}\text { Bottom } \\
\text { Quintile (\%) } \\
\end{array}$ & & $\begin{array}{c}\text { Top Quintile } \\
(\%)\end{array}$ & $\begin{array}{c}\text { II Quintile } \\
(\%)\end{array}$ & $\begin{array}{c}\text { III Quintile } \\
(\%)\end{array}$ & $\begin{array}{c}\text { IV Quintile } \\
(\%)\end{array}$ & $\begin{array}{c}\text { Bottom } \\
\text { Quintile (\%) } \\
\end{array}$ \\
\hline Top Quintile & 73 & 17 & 5 & 1 & 4 & Top Quintile & 76 & 16 & 4 & 2 & 2 \\
\hline II Quintile & 19 & 45 & 24 & 8 & 4 & II Quintile & 17 & 55 & 21 & 5 & 2 \\
\hline III Quintile & 4 & 26 & 42 & 23 & 4 & III Quintile & 3 & 20 & 48 & 25 & 5 \\
\hline IV Quintile & 4 & 9 & 23 & 47 & 17 & IV Quintile & 2 & 6 & 22 & 50 & 20 \\
\hline $\begin{array}{l}\text { Bottom } \\
\text { Quintile }\end{array}$ & 2 & 3 & 8 & 21 & 65 & $\begin{array}{l}\text { Bottom } \\
\text { Quintile }\end{array}$ & 2 & 3 & 6 & 19 & 70 \\
\hline \multicolumn{12}{|c|}{ Outstanding OROS } \\
\hline & $\begin{array}{c}\text { Top Quintile } \\
(\%)\end{array}$ & $\begin{array}{c}\text { II Quintile } \\
(\%)\end{array}$ & $\begin{array}{l}\text { III Quintile } \\
(\%)\end{array}$ & $\begin{array}{c}\text { IV Quintile } \\
(\%)\end{array}$ & $\begin{array}{c}\text { Bottom } \\
\text { Quintile (\%) }\end{array}$ & & $\begin{array}{c}\text { Top Quintile } \\
(\%)\end{array}$ & $\begin{array}{c}\text { II Quintile } \\
(\%)\end{array}$ & $\begin{array}{l}\text { III Quintile } \\
(\%)\end{array}$ & $\begin{array}{c}\text { IV Quintile } \\
(\%)\end{array}$ & $\begin{array}{c}\text { Bottom } \\
\text { Quintile (\%) }\end{array}$ \\
\hline Top Quintile & 62 & 17 & 7 & 8 & 5 & Top Quintile & 76 & 16 & 4 & 2 & 2 \\
\hline II Quintile & 22 & 42 & 22 & 8 & 6 & II Quintile & 17 & 55 & 21 & 5 & 2 \\
\hline III Quintile & 5 & 23 & 40 & 22 & 9 & III Quintile & 3 & 20 & 48 & 25 & 5 \\
\hline IV Quintile & 4 & 10 & 24 & 42 & 20 & IV Quintile & 2 & 6 & 22 & 50 & 20 \\
\hline $\begin{array}{l}\text { Bottom } \\
\text { Quintile }\end{array}$ & 7 & 6 & 10 & 21 & 56 & $\begin{array}{l}\text { Bottom } \\
\text { Quintile }\end{array}$ & 2 & 3 & 6 & 19 & 70 \\
\hline
\end{tabular}

14 - IESE Business School-University of Navarra 
The null hypothesis is rejected for all three performance indicators: diversified firms in the top (and bottom) quintile have at least a 52\% chance of remaining in those quintiles and at most a $7 \%$ chance of moving to the bottom (and top) quintile, while single-segment firms in the top (and bottom) quintile have at least a 59\% chance of remaining in those quintiles and at most a $4 \%$ chance of moving to the bottom (and top) quintile. In addition, we observe that the top and bottom quintiles show higher probabilities of remaining in the same quintile compared with the second, third and fourth quintiles: i.e., for the indicator outstanding ROA (OROA) within diversified firms, the probability of the top and bottom quintiles remaining in their quintile is 63\% and 52\%, respectively, while for the second, third and fourth quintiles, this percentage is $40 \%, 32 \%$ and 40\%, respectively. We find similar figures for the two indicators of outstanding performance. The Markov conditional probabilities confirmed the previous findings using econometric techniques: for both single-segment and diversified firms, there is a significant persistence of outstanding performance for all performance indicators. Firms that outperform during time $t$ have a high probability of outperforming during time $t+1$ and firms that underperform during time $t$ have a high probability of underperforming during time $t+1$. This empirical evidence provides the basis for our research and strengthens our hypothesis that the use of average indicators to estimate the creation or destruction of shareholder value in relation to diversification strategies might not be the appropriate measurement for solving this specific research question.

Because of the persistence of outstanding performance, we do not compare shareholder value creation or market performance between diversified and single-segment firms using the excess value methodology introduced by Berg and Ofek (1995) and commonly used in finance literature. We estimate shareholder value and market performance between diversified and single-segment firms in the same class. We therefore compared the top and bottom quintiles of diversified firms with the top and bottom quintiles of single-segment firms. This classification of similar "performers" into quintiles also allows us to compare top quintiles of diversified firms with top quintiles of single-segment firms, giving investors an additional investment perspective based on the empirical evidence of the persistence of outstanding performance within both single-segment and diversified firms.

We intend to form and compare portfolios with the shares of firms that belong to the distributions' tails and persistently remain in that particular distribution tail during the time series 1999-2000. We find a significant persistence of outstanding performance for all three outstanding performance indicators, OROA, OSALES/ASSETS, and OROS. We form portfolios (one portfolio contains shares of the firms belonging to the top quintile and the other portfolio contains shares of the firms belonging to the bottom quintile) for both diversified and singlesegment firms, based on the ranking obtained from the OROA performance indicator. We use the OROA indicator because of its higher correlation against firm's Tobin's $q$ (firm's Tobin's $q$ is defined in the literature as a well-accepted index of firm's performance) compared with OSALES/ASSETS and OROS, as shown in Table V. 


\section{Table V}

Simple regression between outstanding performance indicators and Tobin's $q$

In order to select the more appropriate performance indicators to construct portfolios of top and bottom quintiles, each indicator of outstanding performance is regressed against Tobin's $q$ for the entire times series 1999-2006. The table gives the simple correlation coefficients between OROA, OROS and OOP/SALES and Tobin's $q$. We separate the results for single-segment firms and diversified firms.

\begin{tabular}{|l|c|c|c|c|c|c|c|c|c|}
\hline Single-segment firms & ORALES/ASSETS & OROS & $\begin{array}{l}\text { Tobin's } \\
q\end{array}$ & & Diversified firms & OROA & OSALES/ASSETS & OROS & $\begin{array}{l}\text { Tobin's } \\
q\end{array}$ \\
\hline OROA & 1 & & & & OROA & 1 & & & \\
\hline OSALES/ASSETS & 0.1009 & 1 & & & OROS & 0.1352 & 1 & & \\
\hline OROS & 0.0425 & 0.0013 & 1 & & OROS & 0.0646 & 0.0028 & 1 & \\
\hline Tobin's $q$ & 0.1828 & 0.0802 & 0.0752 & 1 & $\begin{array}{c}\text { Tobin's } \\
q\end{array}$ & 0.2248 & 0.0840 & 0.0878 & 1 \\
\hline
\end{tabular}


Finally, in order to further confirm the persistence of outstanding performance using the OROA indicator, for every year (2000-2006), we calculate the percentage of firms in the quintiles formed in 1999 that remain within the top and bottom quintiles, respectively, during the entire times series 1999-2006, Table VI. The top quintile group, for both diversified and singlesegment firms, is composed of at least 50\% of the firms until 2004. For the last two years of this series, the firms in the top quintile during 1999 compose at least $40 \%$ of the top quintile groups. We can also see that the firms that were in the top quintile in 1999 always represent at least $65 \%$ of the top and second quintiles in the following year. Within the bottom quintiles, we see a stronger persistence of underperformance (negative outstanding performance) for singlesegment firms: the firms that comprise the bottom quintile in 1999 account for almost 50\% of the bottom quintile during each period during the time series 1999-2006. For diversified firms, we see a lower persistence of underperformance than single-segment firms. In this case, the firms that comprise the bottom quintile in 1999 account for a percentage between 42\% and $57 \%$ of the bottom quintile during each period during the time series 1999-2006. Finally, we also see that single-segment firms always represent at least $67 \%$ of the top and second quintiles in the following year, while the percentage is lower for diversified firms, at 56\%. 


\section{Table VI}

Migration analysis throughout the time series of firms comprising the top and bottom quintiles in 1999

As an additional measurement of the persistence of outstanding performance, for each year and for each top and bottom quintile, we calculate the percentage of the quintile composition, starting in the year 2000, composed of the firms that formed the top and bottom quintile, respectively, in the year 1999 (the beginning of our time series). In other words, we want to estimate how the group of firms that comprised every year the top and bottom quintile change every year with respect to the group formed in 1999. We perform this analysis for single-segment and diversified firms only taking into consideration the OROA as indicator of outstanding performance given that we find that this particular indicator has a higher correlation coefficient with Tobin's $q$ compared with the other two indicators of outstanding performance, OROS and 00P/SALES.

\begin{tabular}{|c|c|c|c|c|c|c|c|c|c|c|c|}
\hline \multicolumn{6}{|c|}{ Diversified Firms } & \multicolumn{6}{|c|}{ Single-segment firms } \\
\hline \multicolumn{12}{|c|}{ TOP Quintiles OROA (\%) } \\
\hline & Top Quintile & II Quintile & III Quintile & IV Quintile & $\begin{array}{l}\text { Bottom } \\
\text { Quintile }\end{array}$ & & Top Quintile & II Quintile & III Quintile & IV Quintile & $\begin{array}{l}\text { Bottom } \\
\text { Quintile }\end{array}$ \\
\hline 1999 & 100 & & & & & 1999 & 100 & & & & \\
\hline 2000 & 65 & 22 & 5 & 5 & 2 & 2000 & 53 & 24 & 5 & 4 & 13 \\
\hline 2001 & 55 & 24 & 12 & 4 & 4 & 2001 & 57 & 22 & 10 & 6 & 5 \\
\hline 2002 & 50 & 24 & 12 & 2 & 9 & 2002 & 58 & 23 & 12 & 5 & 2 \\
\hline 2003 & 50 & 29 & 6 & 8 & 7 & 2003 & 55 & 23 & 8 & 10 & 4 \\
\hline 2004 & 53 & 27 & 12 & 6 & 2 & 2004 & 50 & 19 & 13 & 14 & 4 \\
\hline 2005 & 45 & 24 & 16 & 8 & 6 & 2005 & 46 & 21 & 11 & 11 & 11 \\
\hline 2006 & 41 & 24 & 10 & 16 & 8 & 2006 & 50 & 17 & 8 & 13 & 12 \\
\hline \multicolumn{12}{|c|}{ BOTTOM Quintiles OROA (\%) } \\
\hline & $\begin{array}{l}\text { Bottom } \\
\text { Quintile }\end{array}$ & IV Quintile & III Quintile & II Quintile & Top Quintile & & $\begin{array}{l}\text { Bottom } \\
\text { Quintile }\end{array}$ & IV Quintile & III Quintile & II Quintile & Top Quintile \\
\hline 1999 & 100 & & & & & 1999 & 100 & & & & \\
\hline 2000 & 57 & 29 & 4 & 5 & 5 & 2000 & 67 & 16 & 11 & 4 & 2 \\
\hline 2001 & 47 & 16 & 21 & 7 & 9 & 2001 & 55 & 15 & 11 & 10 & 9 \\
\hline 2002 & 50 & 19 & 13 & 15 & 3 & 2002 & 54 & 15 & 15 & 6 & 9 \\
\hline 2003 & 52 & 15 & 13 & 15 & 5 & 2003 & 51 & 20 & 11 & 4 & 13 \\
\hline 2004 & 43 & 18 & 19 & 7 & 13 & 2004 & 49 & 21 & 12 & 21 & 17 \\
\hline 2005 & 47 & 19 & 17 & 11 & 5 & 2005 & 48 & 18 & 14 & 4 & 16 \\
\hline 2006 & 43 & 13 & 19 & 15 & 9 & 2006 & 51 & 14 & 12 & 4 & 17 \\
\hline
\end{tabular}

18 - IESE Business School-University of Navarra 


\section{Shareholder Value, Market performance and Risk for Single- segment and Diversified Firms}

As previously emphasized, our research does not focus on average measurement of value creation or destruction in relation with diversification. Using empirical evidence on the persistence of outstanding performance, we can calculate and compare shareholder value through the market performance of equal-valued share portfolios of firms belonging to the same quintile. We compare shareholder value between diversified and single-segment firms by a) comparing the market performance (returns, unconditional risk, and Jensen's alpha), and b) attempting to explain the returns' differences using the assets pricing model of Fama and French and the conditional risk (conditional variance and covariance). We perform this analysis for every year and for each portfolio of top and bottom quintiles of single-segment and diversified firms. Moreover, in order to confirm the persistence of outstanding performance found at accounting data level, we also test whether this persistence in outstanding performance is also reflected at market data level. Hence, we also compare the difference between the top and bottom quintiles among diversified and single-segment firms. For every year, four equally balanced portfolios (1\$ invested in each firm) are constructed and the return to shareholders is evaluated. The portfolios are constructed according to the OROA indicator of performance: the first portfolio with firms that belong to the top quintile of diversified firms, the second portfolio with firms that belong to the bottom quintile of diversified firms, the third portfolio with firms that belong to the top quintile of single-segment firms and the fourth portfolio with firms that belong to the bottom quintile of single-segment firms.

\section{A. Risk and total return}

For each portfolio and for every year, the portfolio's total return and standard deviation $(\sigma)$ are calculated as a measurement of the unconditional risk. Table VII shows the results. Except for 2003 (the year of recovery after the recession in 2002), where performance across the top and bottom quintiles and across firms is statistically similar, we do not find any pattern of market underperformance among diversified firms compared with single-segment firms, as would be suggested by previous literature on the "diversification discount." When comparing top quintiles, we noticed that single-segment firms have a statistically significantly higher stock return than diversified firms only in two years (1999 and 2001), but this performance is related to a higher unconditional risk. In the remaining five years, single-segment firms show a statistically significantly higher unconditional risk than diversified firms but with a similar market performance. When we compare the difference in performance in the bottom quintile between single-segment and diversified firms, it is clearly seen that diversified firms outperform single-segment firms with a higher return and a lower risk. Furthermore, when we compare the top quintile of diversified firms and the bottom quintile of single-segment firms, it is clearly seen that diversification creates more shareholder value than single-segment firms. Finally, comparing the difference between top and bottom quintiles among diversified and singlesegment firms, we confirm the classes of top and bottom performers found through accounting data in the previous part. Thus, the persistence of outstanding performance is also confirmed using market data. 


\section{Table VII}

Shareholder value of top and bottom quintiles of diversified and single-segment firms: total return, and standard deviation

Daily market data, for each year and for each portfolio of top and bottom quintiles of single-segment and diversified firms, are used to calculate the total return and the total unconditional risk (the standard deviation $\sigma$ ). Daily market data are taken from Thomson Financial and the total return has been taken into consideration. Panel A shows the yearly return and conditional risk for the four portfolios: top quintile single-segment firms, top quintile diversified firms, bottom quintile single-segment firms and bottom quintile diversified firms. Panel B shows the difference in yearly returns and its statistical significance at 95\% ( $t$ statistics indicated in brackets), and the difference in unconditional risk and the statistical significance (p value) of the inequality of the standard deviations $(\sigma)$. The difference is calculated a) between portfolios of different quintiles (top quintile compared with bottom quintile) for both single-segment and diversified firms, and b) between portfolios of similar quintile types but with different firm classes (single-segment firms compared with diversified firms).

\section{Panel $A$}

\begin{tabular}{|c|c|c|c|c|c|c|c|c|}
\hline \multicolumn{9}{|c|}{ Top quintile single-segment firms (\%) } \\
\hline & 1999 & 2000 & 2001 & 2002 & 2003 & 2004 & 2005 & 2006 \\
\hline Return & 35.16 & 15.85 & 23.26 & -11.21 & 33.48 & 18.86 & 13.50 & 19.41 \\
\hline Unconditional risk $(\sigma)$ & 17.62 & 23.29 & 25.35 & 24.24 & 17.73 & 14.01 & 12.08 & 13.61 \\
\hline \multicolumn{9}{|c|}{ Top quintile diversified firms (\%) } \\
\hline & 1999 & 2000 & 2001 & 2002 & 2003 & 2004 & 2005 & 2006 \\
\hline Return & 16.06 & 11.97 & 11.82 & -6.76 & 37.53 & 23.07 & 14.65 & 19.60 \\
\hline Unconditional risk $(\sigma)$ & 11.23 & 17.98 & 16.14 & 16.96 & 13.18 & 10.55 & 12.55 & 14.61 \\
\hline \multicolumn{9}{|c|}{ Bottom quintile single-segment firms (\%) } \\
\hline & 1999 & 2000 & 2001 & 2002 & 2003 & 2004 & 2005 & 2006 \\
\hline Return & 8.08 & -27.78 & 1.79 & -39.40 & 37.54 & 6.37 & -12.91 & 1.71 \\
\hline Unconditional risk $(\sigma)$ & 16.10 & 22.51 & 22.51 & 24.74 & 39.86 & 15.33 & 13.05 & 14.55 \\
\hline \multicolumn{9}{|c|}{ Bottom quintile diversified firms (\%) } \\
\hline & 1999 & 2000 & 2001 & 2002 & 2003 & 2004 & 2005 & 2006 \\
\hline Return & 2.41 & -13.67 & -0.27 & -26.64 & 40.11 & 12.75 & -8.11 & 11.64 \\
\hline Unconditional risk $(\sigma)$ & 12.56 & 16.39 & 19.18 & 22.59 & 16.96 & 14.37 & 13.36 & 14.86 \\
\hline
\end{tabular}

20 - IESE Business School-University of Navarra 


\section{Table VII (continued)}

Panel $B$

Difference in return and risk between top quintiles of single-segment firms and diversified firms (\%)

\begin{tabular}{|c|c|c|c|c|c|c|c|c|}
\hline & 1999 & 2000 & 2001 & 2002 & 2003 & 2004 & 2005 & 2006 \\
\hline \multirow[t]{2}{*}{ Difference in Total Return } & 19.1 & 3.88 & 11.44 & -4.45 & -4.05 & -4.21 & -1.15 & 0.19 \\
\hline & $(6.11)$ & $(0.93)$ & $(2.66)$ & $(1.04)$ & $(1.27)$ & $(1.69)$ & $(0.47)$ & $(0.06)$ \\
\hline Difference in Unconditional risk $(\sigma)$ & $6.39^{*}$ & $5.31^{\star *}$ & $9.21^{*}$ & $7.28^{*}$ & $4.55^{\star *}$ & $3.46^{\star *}$ & -0.47 & -1 \\
\hline \multicolumn{9}{|c|}{ Difference in return and risk between bottom quintiles of single-segment firms and diversified firms (\%) } \\
\hline & 1999 & 2000 & 2001 & 2002 & 2003 & 2004 & 2005 & 2006 \\
\hline \multirow[t]{2}{*}{ Return } & 5.67 & -14.11 & 2.06 & -12.76 & -2.57 & -6.38 & -4.8 & -9.93 \\
\hline & $(1.75)$ & $(3.36)$ & $(0.48)$ & $(2.58)$ & $(0.42)$ & $(2.14)$ & $(1.75)$ & $(3.14)$ \\
\hline Unconditional risk $(\sigma)$ & 3.54 & $6.12^{\star *}$ & 3.33 & 2.15 & $22.9^{*}$ & 0.96 & -0.31 & -0.31 \\
\hline \multicolumn{9}{|c|}{ Difference in return and risk between top and bottom quintile of diversified firms (\%) } \\
\hline & 1999 & 2000 & 2001 & 2002 & 2003 & 2004 & 2005 & 2006 \\
\hline \multirow[t]{2}{*}{ Difference in Total Return } & 13.65 & 25.64 & 12.09 & 19.88 & -2.58 & 10.32 & 22.76 & 7.96 \\
\hline & $(5.34)$ & $(7.63)$ & $(3.46)$ & $(4.92)$ & $(0.85)$ & $(4.22)$ & $(8.87)$ & $(2.55)$ \\
\hline Difference in Unconditional risk $(\sigma)$ & -1.33 & 1.59 & -3.04 & $-5.63^{*}$ & $-3.78^{\star * \star}$ & $-3.82^{\star \star}$ & -0.81 & -0.25 \\
\hline \multicolumn{9}{|c|}{ Difference in return and risk between top and bottom quintile of single-segment firms (\%) } \\
\hline & 1999 & 2000 & 2001 & 2002 & 2003 & 2004 & 2005 & 2006 \\
\hline \multirow[t]{2}{*}{ Difference in Total Return } & 27.08 & 43.63 & 21.47 & 28.19 & -4.06 & 12.49 & 26.41 & 17.7 \\
\hline & $(7.20)$ & $(8.61)$ & $(4.20)$ & $(5.35)$ & $(0.64)$ & $(4.06)$ & $(10.08)$ & $(5.92)$ \\
\hline Difference in Unconditional risk $(\sigma)$ & 1.52 & 0.78 & 2.84 & -0.5 & $-22.13^{\star}$ & -1.32 & -0.97 & -0.94 \\
\hline \multicolumn{9}{|c|}{ Difference in return and risk between top quintile of diversified firms and bottom quintile of single-segment firms (\%) } \\
\hline & 1999 & 2000 & 2001 & 2002 & 2003 & 2004 & 2005 & 2006 \\
\hline \multirow[t]{2}{*}{ Return } & 7.98 & 39.75 & 10.03 & 33.14 & -0.01 & 16.7 & 27.56 & 17.89 \\
\hline & $(2.60)$ & $(9.14)$ & $(2.48)$ & $(6.92)$ & $(0.00)$ & $(6.22)$ & $(10.52)$ & $(5.78)$ \\
\hline Unconditional risk $(\sigma)$ & $-4.87^{* *}$ & $-4.53^{\star *}$ & $-6.37^{* *}$ & $-7.78^{*}$ & $-26.68^{*}$ & $-4.78^{\star *}$ & -0.5 & 0.06 \\
\hline
\end{tabular}

${ }^{*} p<0.01,{ }^{* *} p<0.05,{ }^{* * *} p<0.10$. 


\section{B. Jensen's alpha}

Jensen's alpha (Jensen, 1969) measures the systematic risk-adjusted excess return with respect to a selected reference market according to the formula:

$$
\begin{aligned}
& \mathrm{R} p-\mathrm{R} f=\beta p(\mathrm{R} m-\mathrm{R} f)+\text { Alpha } \\
& \text { Alpha }=\mathrm{R} p-\beta p(\mathrm{R} m-\mathrm{R} f)-\mathrm{R} f
\end{aligned}
$$

$\mathrm{R} p$ represents the return of the top and bottom quintile portfolios, $\mathrm{R} f$ is the risk-free rate, $\mathrm{R} m$ is the market return and $\beta p$ is the covariance of the portfolio's returns scaled by the variance of the return on the market.

Jensen's alpha is calculated according to the S\&P 500 Composite; the data are taken on a daily basis. 


\section{Table VIII}

Jensen's alpha of the top and bottom quintiles in diversified and single-segment firms

Daily market data, for each year and for each portfolio of top and bottom quintiles of diversified and single-segment firms, are used to calculate Jensen's alpha in order to compare the financial performance with a market reference. Daily market data are taken from Thomson Financial and the total return has been taken into consideration. Jensen's alpha is calculated according to the following formula: Alpha $=\mathrm{R} p-\beta p$ (Rm-Rf) - Rf, where $\mathrm{R} p$ represents the return of the top and bottom quintile portfolio, $\mathrm{R} f$ is the risk-free rate, $\mathrm{R} m$ is the market return and $\beta p$ is the covariance of the portfolio's returns scaled by the variance of the market return. The S\&P 500 Composite index has been taken as reference market (market index). The correlation between the market index and the portfolio is shown in brackets.

\begin{tabular}{|c|c|c|c|c|c|c|c|c|}
\hline \multicolumn{9}{|c|}{ Top quintile single-segment firms (\%) } \\
\hline & 1999 & 2000 & 2001 & 2002 & 2003 & 2004 & 2005 & 2006 \\
\hline Jensen's alpha & $\begin{array}{l}24.09 \\
(0.60)\end{array}$ & $\begin{array}{l}29.23 \\
(0.70)\end{array}$ & $\begin{array}{l}40.08 \\
(0.75)\end{array}$ & $\begin{array}{l}11.50 \\
(0.83)\end{array}$ & $\begin{array}{l}12.44 \\
(0.69)\end{array}$ & $\begin{array}{r}8.98 \\
(0.74)\end{array}$ & $\begin{array}{l}11.68 \\
(0.74)\end{array}$ & $\begin{array}{r}8.19 \\
(0.71)\end{array}$ \\
\hline \multicolumn{9}{|c|}{ Top quintile diversified firms (\%) } \\
\hline & 1999 & 2000 & 2001 & 2002 & 2003 & 2004 & 2005 & 2006 \\
\hline Jensen's alpha & $\begin{array}{c}10.83 \\
(0.34)\end{array}$ & $\begin{array}{l}19.31 \\
(0.58)\end{array}$ & $\begin{array}{l}22.31 \\
(0.70)\end{array}$ & $\begin{array}{r}8.35 \\
(0.75)\end{array}$ & $\begin{array}{l}21.04 \\
(0.78)\end{array}$ & $\begin{array}{l}14.65 \\
(0.75)\end{array}$ & $\begin{array}{l}12.74 \\
(0.75)\end{array}$ & $\begin{array}{r}7.70 \\
(0.69)\end{array}$ \\
\hline \multicolumn{9}{|c|}{ Bottom quintile single-segment firms (\%) } \\
\hline & 1999 & 2000 & 2001 & 2002 & 2003 & 2004 & 2005 & 2006 \\
\hline Jensen's alpha & $\begin{array}{r}-0.76 \\
(0.27)\end{array}$ & $\begin{array}{r}-47.82 \\
(0.41)\end{array}$ & $\begin{array}{l}15.51 \\
(0.62)\end{array}$ & $\begin{array}{r}-17.80 \\
(0.73)\end{array}$ & $\begin{array}{l}17.80 \\
(0.12)\end{array}$ & $\begin{array}{r}-2.91 \\
(0.55)\end{array}$ & $\begin{array}{r}-14.55 \\
(0.51)\end{array}$ & $\begin{array}{r}-9.80 \\
(0.65)\end{array}$ \\
\hline \multicolumn{9}{|c|}{ Bottom quintile diversified firms (\%) } \\
\hline & 1999 & 2000 & 2001 & 2002 & 2003 & 2004 & 2005 & 2006 \\
\hline Jensen's alpha & $\begin{array}{r}-4.59 \\
(0.26)\end{array}$ & $\begin{array}{r}-5.83 \\
(0.48)\end{array}$ & $\begin{array}{l}10.19 \\
(0.49)\end{array}$ & $\begin{array}{r}-7.25 \\
(0.70)\end{array}$ & $\begin{array}{l}20.26 \\
(0.68)\end{array}$ & $\begin{array}{r}3.71 \\
(0.68)\end{array}$ & $\begin{array}{r}-9.80 \\
(0.52)\end{array}$ & $\begin{array}{r}0.04 \\
(0.63)\end{array}$ \\
\hline
\end{tabular}


It can be seen from Table VIII that the performance of the two top quintile portfolios is similar to that found in the risk and return analysis: we found that single-segment firms show a superior performance from 1999 to 2002. For the remaining period, diversified firms show a slightly higher Jensen's alpha. Unlike the bottom quintile portfolios, the portfolio composed of diversified firms clearly shows a higher Jensen's alpha than the portfolio of single-segment firms, which clearly and consistently underperforms the market. As in the previous analysis (return and unconditional risk), we do not find any consistent evidence that single-segment firms outperform diversified firms. Within the top quintiles, single-segment firms' superior performance is only clearly present during the first four years, while during the rest of the time series the opposite is the case. Compared with the bottom quintiles, we found evidence that the of bottom quintile portfolio of diversified firms clearly outperforms the portfolio of single-segment firms, which clearly underperforms the market in seven years out of eight.

We also confirm the persistence of outstanding performance within single-segment and diversified firms found in the previous section: Jensen's alpha between the top quintile portfolios and the bottom quintile portfolios is always positive and significant; within singlesegment firms, this difference is very important. Moreover, the top quintile portfolios always beat the market during the years when the bottom quintile portfolios underperform the market.

\section{Fama \& French three-factor model}

The basic statistics have shown two important differences between single-segment firms and diversified firms, which are included in the expected return: a) single-segment firms have a smaller size than diversified firms, and b) single-segment firms compete in industries with higher ME/BE multiples than diversified firms. We therefore analyse whether these specific characteristics of single-segment and diversified firms might explain the difference in returns using Fama and French's asset pricing model to explain the portfolio's extra return (the portfolio's return minus the risk-free rate) taking into account the extra return or "risk premium" that investors ask for with respect to a "size premium" and "value premium", in addition to the premium related to the systematic risk.

Fama and French's multifactor asset pricing model was grounded on the empirical finding that size (SMB) and the book-to-market equity ratio (HML) have a consistent, significant explanatory power for stock returns (Fama and French, 1992).

The Fama and French three-factor model follows this formula:

$$
\mathrm{R} p=\mathrm{R} f+b i(\mathrm{R} m-\mathrm{R} f)+s i \mathrm{SMB}+h i \mathrm{HML}
$$

Where:

$\mathrm{R} m-\mathrm{R} f$ factor: Market premium, equal to the CAPM (Sharpe, 1964). This measurement allows the systematic risk known as the market risk, or the risk that cannot be diversified away and is not specific to individual stock to be compared for both portfolios.

$S M B$ factor: This stands for Small Minus Big, and accounts for the "size premium". It is also conditionally related to profitability (Fama and French, 1992). It is designed to measure the additional return that investors have historically received by investing in stocks of companies with a relatively low market capitalization. Logically, this factor would be expected to be more sensitive to a large number of risk factors due to their relatively undiversified nature and their 
reduced ability to absorb negative financial stock. Fama and French (1992) observe that the 1981-1982 recession turns into a prolonged earning depression for small stocks and also that, on average, small stocks do not participate in the boom of the middle and late 1980's.

HML factor: This stands for High Minus Low and accounts for the "value premium." It is more related to profitability than the SMB factor (Fama and French, 1992). It is designed to measure the additional return provided to investors by investing in companies with high book-to-market values. Fama and French (1995) show that book-to-market equity and the slope on HML proxy for relative for distress: weak firms with persistently low earnings tend to have a high BE/ME (book equity/market equity ratio) and a positive slope on HML, while strong firms with persistently high earnings have a low BE/ME and a negative slope on HML.

We regress each top and bottom quintile for both single-segment and diversified firms against the Fama and French three factors. We also regress the difference in returns between these portfolios within the same quintile class.

Table IX shows the results. 


\section{Table IX}

\section{Regression of top and bottom quintile returns against the Fama and French three-factor model}

The daily return of the top and bottom quintile portfolios of diversified and single-segment firms is regressed against the Fama and French three-factor model according to the formula $(\mathrm{R} p-\mathrm{R} f)=\alpha+b i(\mathrm{R} m-\mathrm{R} f)+s i \mathrm{SMB}+h i \mathrm{HML}$. Rm is the return on the value-weighted index of NYSE, Amex, and Nasdaq stocks on day $t$; $\mathrm{Rf}_{\mathrm{t}}$ is the beginning-of-month three-month T-bill yield on day $t, \mathrm{SMB}_{\mathrm{t}}$ is the return on small firms minus the return on large firms on day $t$, and $\mathrm{HML}_{\mathrm{t}}$ is the return on high book-to-market stocks minus the return on low book-to-market stocks on day $t$. The factor definitions are described in Fama and French (1993).

The regression is performed for every year and for the entire time series 1999-2006. The daily difference in return between the top quintile portfolios (single-segment firms minus diversified firms) and the bottom quintile portfolios is also regressed in the same way (for each year and for the entire time series) against the Fama and French three-factor model, according to the formula $(\Delta \mathrm{R} p-\mathrm{R} f)=\alpha+b i(\mathrm{R} m-\mathrm{R} f)+s i \mathrm{SMB}+h i \mathrm{HML}$, where the term $\Delta \mathrm{R} p$ is the difference in return between portfolios. T-statistics are in brackets. Panel A contains the results of the regressions for the top quintiles, Panel B contains the results of the regressions for the bottom quintiles, and Panel C contains the results of the regressions between the top and bottom quintiles of single-segment and diversified firms.

\section{Panel A: Top Quintiles}

\begin{tabular}{|c|c|c|c|c|c|c|c|c|}
\hline \multicolumn{9}{|c|}{ Top quintile single-segment firms (yearly) } \\
\hline Coefficients & 1999 & 2000 & 2001 & 2002 & 2003 & 2004 & 2005 & 2006 \\
\hline$R_{A d j}^{2}$ & 0.73 & 0.81 & 0.84 & 0.91 & 0.80 & 0.85 & 0.87 & 0.84 \\
\hline$b$ (Market) & 0.106 & 0.0098 & $\begin{array}{r}0.116 \\
(26.17)\end{array}$ & 0.0102 & 0.0096 & 0.0093 & 0.0086 & 0.0087 \\
\hline$s(\mathrm{SMB})$ & $\begin{array}{r}(15.94) \\
0.0053 \\
(6.85)\end{array}$ & $\begin{array}{r}(18.41) \\
0.0022 \\
(4.08)\end{array}$ & $\begin{array}{r}(26.17) \\
0.0063 \\
(8.60)\end{array}$ & $\begin{array}{l}(42.49) \\
0.0051 \\
(10.33)\end{array}$ & $\begin{array}{r}(28.55) \\
0.0052 \\
(9.17)\end{array}$ & $\begin{array}{r}(25.18) \\
0.0044 \\
(8.57)\end{array}$ & $\begin{array}{l}(28.06) \\
0.0052 \\
(10.89)\end{array}$ & $\begin{array}{r}(20.59) \\
0.0050 \\
(8.14)\end{array}$ \\
\hline$h(\mathrm{HLM})$ & $\begin{array}{r}0.0013 \\
(1.66)\end{array}$ & $\begin{array}{r}0.0026 \\
(3.26)\end{array}$ & $\begin{array}{r}0.0025 \\
(3.71)\end{array}$ & $\begin{array}{r}0.0014 \\
(2.54)\end{array}$ & $\begin{array}{r}-0.0008 \\
(0.83)\end{array}$ & $\begin{array}{r}-0.0005 \\
(0.97)\end{array}$ & $\begin{array}{r}-0.0012 \\
(2.22)\end{array}$ & $\begin{array}{r}-0.0020 \\
(2.15)\end{array}$ \\
\hline$\alpha$ & $\begin{array}{r}0.0003 \\
(0.92)\end{array}$ & $\begin{array}{r}0.0006 \\
(1.48)\end{array}$ & $\begin{array}{r}0.0001 \\
(2.25)\end{array}$ & $\begin{array}{r}0.0002 \\
(0.89)\end{array}$ & $\begin{array}{r}-0.0002 \\
(0.66)\end{array}$ & $\begin{array}{r}0.0002 \\
(0.91)\end{array}$ & $\begin{array}{r}0.00032 \\
(1.79)\end{array}$ & $\begin{array}{r}0.0002 \\
(1.20)\end{array}$ \\
\hline $\begin{array}{l}\text { Top quintile } \\
\text { R2 } \\
\text { b(Market) }\end{array}$ & $\begin{array}{r}\text { firms (19 } \\
0.82 \\
0.010 \\
(76.88)\end{array}$ & & & & & & & \\
\hline $\mathrm{s}(\mathrm{SMB})$ & $\begin{array}{l}0.0038 \\
(20.79)\end{array}$ & & & & & & & \\
\hline$h(H L M)$ & $\begin{array}{r}0.0016 \\
(7.16)\end{array}$ & & & & & & & \\
\hline$\alpha$ & $\begin{array}{r}0,00034 \\
(3.01)\end{array}$ & & & & & & & \\
\hline
\end{tabular}


Table IX (continued)

\begin{tabular}{|c|c|c|c|c|c|c|c|c|}
\hline \multicolumn{9}{|c|}{ Top quintile diversified firms (yearly) } \\
\hline Coefficients & 1999 & 2000 & 2001 & 2002 & 2003 & 2004 & 2005 & 2006 \\
\hline$R^{2}$ & 0.51 & 0.65 & 0.80 & 0.86 & 0.86 & 0.85 & 0.91 & 0.84 \\
\hline$b$ (Market) & $\begin{array}{l}0.0082 \\
(14.37)\end{array}$ & $\begin{array}{l}0.0088 \\
(15.46)\end{array}$ & $\begin{array}{l}0.0080 \\
(24.79)\end{array}$ & $\begin{array}{l}0.0075 \\
(36.75)\end{array}$ & $\begin{array}{l}0.0079 \\
(37.76)\end{array}$ & $\begin{array}{l}0.0083 \\
(27.12)\end{array}$ & $\begin{array}{l}0.0094 \\
(34.82)\end{array}$ & $\begin{array}{r}0.10 \\
(22.43)\end{array}$ \\
\hline$s(\mathrm{SMB})$ & $\begin{array}{r}0.0047 \\
(7.00)\end{array}$ & $\begin{array}{r}0.0015 \\
(2.50)\end{array}$ & $\begin{array}{r}0.0038 \\
(7.15)\end{array}$ & $\begin{array}{r}0.0038 \\
(9.02)\end{array}$ & $\begin{array}{r}0.0028 \\
(8.11)\end{array}$ & $\begin{array}{r}0.0032 \\
(7.54)\end{array}$ & $\begin{array}{r}0.0054 \\
(12.89)\end{array}$ & $\begin{array}{r}0.0057 \\
(8.83)\end{array}$ \\
\hline$h(\mathrm{HLM})$ & $\begin{array}{r}0.0058 \\
(8.03)\end{array}$ & $\begin{array}{r}0.0051 \\
(6.00)\end{array}$ & $\begin{array}{r}0.0036 \\
(7.31)\end{array}$ & $\begin{array}{r}0.0042 \\
(8.61)\end{array}$ & $\begin{array}{r}0.0024 \\
(3.80)\end{array}$ & $\begin{array}{r}0.0015 \\
(3.12)\end{array}$ & $\begin{array}{r}0.0038 \\
(7.51)\end{array}$ & $\begin{array}{r}0.0033 \\
(3.41)\end{array}$ \\
\hline$\alpha$ & $\begin{array}{r}0.00036 \\
(1.17)\end{array}$ & $\begin{array}{r}0.00015 \\
(0.035)\end{array}$ & $\begin{array}{r}0.0005 \\
(1.76)\end{array}$ & $\begin{array}{r}0.0001 \\
(0.63)\end{array}$ & $\begin{array}{r}0.0003 \\
(1.63)\end{array}$ & $\begin{array}{r}0.0003 \\
(2.20)\end{array}$ & $\begin{array}{r}0.0003 \\
(2.02)\end{array}$ & $\begin{array}{r}0.0001 \\
(0.58)\end{array}$ \\
\hline \multicolumn{9}{|c|}{ Top quintile diversified firms (1999-2006) } \\
\hline$R$ & 0.76 & & & & & & & \\
\hline$b$ (Market) & $\begin{array}{l}0.0083 \\
(73.16)\end{array}$ & & & & & & & \\
\hline$s(\mathrm{SMB})$ & $\begin{array}{l}0.0036 \\
(21.82)\end{array}$ & & & & & & & \\
\hline$h(\mathrm{HLM})$ & $\begin{array}{l}0.0048 \\
(24.62)\end{array}$ & & & & & & & \\
\hline$\alpha$ & $\begin{array}{r}0.00026 \\
(2.65)\end{array}$ & & & & & & & \\
\hline \multicolumn{9}{|c|}{ Difference top quintiles single-segment and diversified firms (yearly) } \\
\hline Coefficients & 1999 & 2000 & 2001 & 2002 & 2003 & 2004 & 2005 & 2006 \\
\hline$R$ & 0.38 & 0.31 & 0.40 & 0.45 & 0.21 & 0.11 & 0.19 & 0.09 \\
\hline$b$ (Market) & $\begin{array}{r}0.0023 \\
(2.98)\end{array}$ & $\begin{array}{r}0.0010 \\
(1.96)\end{array}$ & $\begin{array}{r}0.0035 \\
(6.76)\end{array}$ & $\begin{array}{r}0.0026 \\
(9.44)\end{array}$ & $\begin{array}{r}0.0017 \\
(4.86)\end{array}$ & $\begin{array}{r}0.0010 \\
(2.20)\end{array}$ & $\begin{array}{r}-0.007 \\
(2.14)\end{array}$ & $\begin{array}{r}-0.0013 \\
(2.32)\end{array}$ \\
\hline$s(\mathrm{SMB})$ & $\begin{array}{r}0.0006 \\
(0.68)\end{array}$ & $\begin{array}{r}0.00078 \\
(1.22)\end{array}$ & $\begin{array}{r}0.0024 \\
(2.85)\end{array}$ & $\begin{array}{r}0.0013 \\
(2.25)\end{array}$ & $\begin{array}{l}0.022 \\
(3.94)\end{array}$ & $\begin{array}{r}0.0012 \\
(1.96)\end{array}$ & $\begin{array}{r}0.0002 \\
(0.37)\end{array}$ & $\begin{array}{r}-0.0007 \\
(0.89)\end{array}$ \\
\hline$h(\mathrm{HLM})$ & $\begin{array}{r}-0.0044 \\
(4.37)\end{array}$ & $\begin{array}{r}-0.0024 \\
(2.66)\end{array}$ & $\begin{array}{r}-0.0011 \\
(1.43)\end{array}$ & $\begin{array}{r}-0.0027 \\
(4.06)\end{array}$ & $\begin{array}{r}-0.0032 \\
(3.04)\end{array}$ & $\begin{array}{r}-0.0021 \\
(2.85)\end{array}$ & $\begin{array}{r}-0.0051 \\
(7.43)\end{array}$ & $\begin{array}{r}-0.0053 \\
(4.39)\end{array}$ \\
\hline$\alpha$ & $\begin{array}{r}-0.0001 \\
(0.08) \\
\end{array}$ & $\begin{array}{r}0.0004 \\
(0.95) \\
\end{array}$ & $\begin{array}{r}0.0003 \\
(0.75) \\
\end{array}$ & $\begin{array}{r}0.0001 \\
(0.30) \\
\end{array}$ & $\begin{array}{r}-0.0005 \\
(1.66) \\
\end{array}$ & $\begin{array}{r}-0.0002 \\
(0.73) \\
\end{array}$ & $\begin{array}{r}0.0001 \\
(0.10) \\
\end{array}$ & $\begin{array}{r}0.0001 \\
(0.44) \\
\end{array}$ \\
\hline
\end{tabular}




\section{Table IX (continued)}

$\begin{array}{lc}\text { Difference top quintiles single-segment and diversified firms (1999-2006) } \\ R^{2} & 0.27 \\ b \text { (Market) } & 0.0017 \\ & (10.78) \\ s(\mathrm{SMB}) & 0.00021 \\ & (0.95) \\ h(\mathrm{HLM}) & -0.0032 \\ & (12.43) \\ \alpha & 0.0001 \\ & (0.57)\end{array}$

\section{Panel B. Bottom Quintiles}

Bottom quintile single-segment firms (yearly)

\begin{tabular}{|c|c|c|c|c|c|c|c|c|}
\hline & 1999 & 2000 & 2001 & 2002 & 2003 & 2004 & 2005 & 2006 \\
\hline$R$ & 0.50 & 0.60 & 0.74 & 0.81 & 0.15 & 0.66 & 0.61 & 0.81 \\
\hline$b$ (Market) & $\begin{array}{r}0.0120 \\
(14.43)\end{array}$ & $\begin{array}{r}0.0089 \\
(11.98)\end{array}$ & $\begin{array}{r}0.0096 \\
(18.71)\end{array}$ & $\begin{array}{l}0.0102 \\
(29.97)\end{array}$ & $\begin{array}{r}0.0096 \\
(5.94)\end{array}$ & $\begin{array}{r}0.0089 \\
(14.71)\end{array}$ & $\begin{array}{r}0.078 \\
(13.42)\end{array}$ & $\begin{array}{c}0.0095 \\
(19.28)\end{array}$ \\
\hline$s(\mathrm{SMB})$ & $\begin{array}{r}0.0090 \\
(9.27)\end{array}$ & $\begin{array}{r}0.0053 \\
(6.95)\end{array}$ & $\begin{array}{r}0.0076 \\
(8.85)\end{array}$ & $\begin{array}{r}0.0059 \\
(8.42)\end{array}$ & $\begin{array}{r}0.0032 \\
(1.19)\end{array}$ & $\begin{array}{r}0.0048 \\
(5.76)\end{array}$ & $\begin{array}{r}0.0051 \\
(5.63)\end{array}$ & $\begin{array}{r}0.0060 \\
(8.43)\end{array}$ \\
\hline$h(\mathrm{HLM})$ & $\begin{array}{r}0.0081 \\
(7.75)\end{array}$ & $\begin{array}{r}0.0046 \\
(4.10)\end{array}$ & $\begin{array}{r}0.0026 \\
(3.35)\end{array}$ & $\begin{array}{r}0.0027 \\
(3.33)\end{array}$ & $\begin{array}{r}0.0047 \\
(0.97)\end{array}$ & $\begin{array}{r}0.0020 \\
(2.05)\end{array}$ & $\begin{array}{r}0.0011 \\
(1.04)\end{array}$ & $\begin{array}{r}0.0037 \\
(3.45)\end{array}$ \\
\hline$\alpha$ & $\begin{array}{r}-0.0002 \\
(0.59)\end{array}$ & $\begin{array}{r}-0.0013 \\
(2.51)\end{array}$ & $\begin{array}{r}-0.0001 \\
(0.4)\end{array}$ & $\begin{array}{r}-0.0008 \\
(2.13)\end{array}$ & $\begin{array}{r}0.00003 \\
(0.03)\end{array}$ & $\begin{array}{r}-0.0003 \\
(1.00)\end{array}$ & $\begin{array}{r}-0.0008 \\
(2.46)\end{array}$ & $\begin{array}{r}-0.0007 \\
(2.94)\end{array}$ \\
\hline \multicolumn{9}{|c|}{ Bottom quintile single-segment firms (1999-2006) } \\
\hline$R$ & 0.47 & & & & & & & \\
\hline$b$ (Market) & $\begin{array}{l}0.0094 \\
(35.70)\end{array}$ & & & & & & & \\
\hline$s(\mathrm{SMB})$ & $\begin{array}{l}0.0054 \\
(13.98)\end{array}$ & & & & & & & \\
\hline$h(\mathrm{HLM})$ & $\begin{array}{r}0.0039 \\
(8.49)\end{array}$ & & & & & & & \\
\hline$\alpha$ & $\begin{array}{r}-0.0006 \\
(2.72)\end{array}$ & & & & & & & \\
\hline
\end{tabular}

28 - IESE Business School-University of Navarra 


\section{Table IX (continued)}

Bottom quintile diversified firms (yearly)

\begin{tabular}{|c|c|c|c|c|c|c|c|c|}
\hline & 1999 & 2000 & 2001 & 2002 & 2003 & 2004 & 2005 & 2006 \\
\hline$R$ & 0.61 & 0.55 & 0.69 & 0.84 & 0.77 & 0.82 & 0.67 & 0.81 \\
\hline$b$ (Market) & $\begin{array}{r}0.011 \\
(19.95)\end{array}$ & $\begin{array}{l}0.0075 \\
(13.02)\end{array}$ & $\begin{array}{l}0.0098 \\
(20.62)\end{array}$ & $\begin{array}{l}0.0101 \\
(34.78)\end{array}$ & $\begin{array}{l}0.0096 \\
(27.73)\end{array}$ & $\begin{array}{l}0.0089 \\
(21.56)\end{array}$ & $\begin{array}{l}0.0080 \\
(14.57)\end{array}$ & $\begin{array}{l}0.0093 \\
(18.63)\end{array}$ \\
\hline$s(\mathrm{SMB})$ & $\begin{array}{l}0.0070 \\
(10.42)\end{array}$ & $\begin{array}{r}0.0021 \\
(3.56)\end{array}$ & $\begin{array}{r}0.0078 \\
(9.84)\end{array}$ & $\begin{array}{l}0.0063 \\
(10.37)\end{array}$ & $\begin{array}{r}0.0037 \\
(6.23)\end{array}$ & $\begin{array}{r}0.0057 \\
(9.92)\end{array}$ & $\begin{array}{r}0.0062 \\
(7.25)\end{array}$ & $\begin{array}{l}0.0073 \\
(10.11)\end{array}$ \\
\hline$h(\mathrm{HLM})$ & $\begin{array}{c}0.0099 \\
(13.83)\end{array}$ & $\begin{array}{r}0.0047 \\
(5.52)\end{array}$ & $\begin{array}{r}0.0072 \\
(9.84)\end{array}$ & $\begin{array}{r}0.0067 \\
(9.46)\end{array}$ & $\begin{array}{r}0.0036 \\
(3.44)\end{array}$ & $\begin{array}{r}0.0011 \\
(1.71)\end{array}$ & $\begin{array}{r}0.0037 \\
(3.60)\end{array}$ & $\begin{array}{r}0.0067 \\
(6.10)\end{array}$ \\
\hline$\alpha$ & $\begin{array}{r}-0.0001 \\
(0.58)\end{array}$ & $\begin{array}{r}-0.0010 \\
(2.33)\end{array}$ & $\begin{array}{r}-0.0005 \\
(1.26)\end{array}$ & $\begin{array}{r}-0.0006 \\
(1.66)\end{array}$ & $\begin{array}{r}0.0002 \\
(0.65)\end{array}$ & $\begin{array}{r}0.00006 \\
(0.28)\end{array}$ & $\begin{array}{r}-0.0006 \\
(2.20)\end{array}$ & $\begin{array}{r}-0.0004 \\
(1.79)\end{array}$ \\
\hline \multicolumn{9}{|c|}{ Bottom quintile diversified firms (1999-2006) } \\
\hline $\mathrm{R}$ & 0.71 & & & & & & & \\
\hline $\mathrm{b}$ (Market) & $\begin{array}{l}0.0094 \\
(66.27)\end{array}$ & & & & & & & \\
\hline s(SMB) & $\begin{array}{l}0.0049 \\
(23.69)\end{array}$ & & & & & & & \\
\hline h(HLM) & $\begin{array}{l}0.0069 \\
(27.85)\end{array}$ & & & & & & & \\
\hline$\alpha$ & $\begin{array}{r}-0.0004 \\
(3.95)\end{array}$ & & & & & & & \\
\hline
\end{tabular}




\section{Table IX (continued)}

\begin{tabular}{|c|c|c|c|c|c|c|c|c|}
\hline \multicolumn{9}{|c|}{ Difference bottom quintiles single-segment and diversified firms (yearly) } \\
\hline & 1999 & 2000 & 2001 & 2002 & 2003 & 2004 & 2005 & 2006 \\
\hline$R$ & 0.07 & 0.15 & 0.18 & 0.07 & 0.01 & 0.04 & 0.01 & 0.06 \\
\hline$b$ (Market) & $\begin{array}{r}0.0008 \\
(1.02)\end{array}$ & $\begin{array}{r}0.0014 \\
(1.51)\end{array}$ & $\begin{array}{r}-0.0002 \\
(0.39)\end{array}$ & $\begin{array}{r}0.0001 \\
(0.22)\end{array}$ & $\begin{array}{r}-0.0001 \\
(0.03)\end{array}$ & $\begin{array}{r}0.0001 \\
(0.04)\end{array}$ & $\begin{array}{r}-0.0021 \\
(0.27)\end{array}$ & $\begin{array}{r}0.0002 \\
(0.28)\end{array}$ \\
\hline$s(\mathrm{SMB})$ & $\begin{array}{r}0.0020 \\
(2.03)\end{array}$ & $\begin{array}{r}0.0032 \\
(3.35)\end{array}$ & $\begin{array}{r}-0.0002 \\
(0.25)\end{array}$ & $\begin{array}{r}-0.0003 \\
(0.35)\end{array}$ & $\begin{array}{r}-0.0041 \\
(0.15)\end{array}$ & $\begin{array}{r}0.0008 \\
(0.84)\end{array}$ & $\begin{array}{r}-0.0011 \\
(0.90)\end{array}$ & $\begin{array}{r}0.0013 \\
(1.32)\end{array}$ \\
\hline$h(\mathrm{HLM})$ & $\begin{array}{r}-0.0018 \\
(1.69)\end{array}$ & $\begin{array}{r}-0.0002 \\
(0.14)\end{array}$ & $\begin{array}{r}-0.0046 \\
(4.95)\end{array}$ & $\begin{array}{r}-0.0039 \\
(3.79)\end{array}$ & $\begin{array}{r}0.0011 \\
(0.23)\end{array}$ & $\begin{array}{r}0.0008 \\
(0.75)\end{array}$ & $\begin{array}{r}0.0026 \\
(1.75)\end{array}$ & $\begin{array}{r}0.0029 \\
(1.99)\end{array}$ \\
\hline$\alpha$ & $\begin{array}{r}-0.0002 \\
(0.57)\end{array}$ & $\begin{array}{r}0.0006 \\
(0.88)\end{array}$ & $\begin{array}{r}0.0002 \\
(0.38)\end{array}$ & $\begin{array}{r}0.0004 \\
(0.69)\end{array}$ & $\begin{array}{r}-0.0002 \\
(-0.14)\end{array}$ & $\begin{array}{r}-0.0003 \\
(0.81)\end{array}$ & $\begin{array}{r}-0.0002 \\
(0.55)\end{array}$ & $\begin{array}{r}0.0004 \\
(1.34)\end{array}$ \\
\hline \multicolumn{9}{|c|}{ Difference bottom quintiles single-segment and diversified firms (1999-2006) } \\
\hline $\mathrm{R}$ & 0.03 & & & & & & & \\
\hline b(Market) & $\begin{array}{r}0.00001 \\
(0.05)\end{array}$ & & & & & & & \\
\hline $\mathrm{s}(\mathrm{SMB})$ & $\begin{array}{r}0.0005 \\
(1.16)\end{array}$ & & & & & & & \\
\hline $\mathrm{h}(\mathrm{HLM})$ & $\begin{array}{r}-0.0029 \\
(6.01)\end{array}$ & & & & & & & \\
\hline$\alpha$ & $\begin{array}{r}-0.0002 \\
(1.06)\end{array}$ & & & & & & & \\
\hline
\end{tabular}

30 - IESE Business School-University of Navarra 


\section{Table IX (continued)}

Panel C: Difference between top and bottom quintiles

\begin{tabular}{|c|c|c|c|c|c|c|c|c|}
\hline \multicolumn{9}{|c|}{ Difference between top and bottom quintiles within diversified firms (yearly) } \\
\hline & 1999 & 2000 & 2001 & 2002 & 2003 & 2004 & 2005 & 2006 \\
\hline$R^{2}$ & 0.07 & 0.05 & 0.11 & 0.24 & 0.09 & 0.12 & 0.03 & 0.04 \\
\hline$b$ (Market) & $\begin{array}{r}-0.0287 \\
(3.83)\end{array}$ & $\begin{array}{r}0.0012 \\
(2.10)\end{array}$ & $\begin{array}{r}-0.0018 \\
(3.29)\end{array}$ & $\begin{array}{r}-0.0026 \\
(8.10)\end{array}$ & $\begin{array}{r}-0.0018 \\
(4.62)\end{array}$ & $\begin{array}{r}-0.006 \\
(1.25)\end{array}$ & $\begin{array}{r}0.0015 \\
(2.44)\end{array}$ & $\begin{array}{r}0.0006 \\
(1.13)\end{array}$ \\
\hline$s(\mathrm{SMB})$ & $\begin{array}{r}-0.0023 \\
(2.58)\end{array}$ & $\begin{array}{r}-0.0006 \\
(1.10)\end{array}$ & $\begin{array}{r}-0.0040 \\
(4.39)\end{array}$ & $\begin{array}{r}-0.0024 \\
(3.65)\end{array}$ & $\begin{array}{r}-0.0008 \\
(1.24)\end{array}$ & $\begin{array}{r}-0.0024 \\
(3.74)\end{array}$ & $\begin{array}{r}-0.0008 \\
(0.86)\end{array}$ & $\begin{array}{r}-0.0016 \\
(1.89)\end{array}$ \\
\hline$h(\mathrm{HLM})$ & $\begin{array}{r}-0.0081 \\
(4.39)\end{array}$ & $\begin{array}{r}0.0003 \\
(0.34)\end{array}$ & $\begin{array}{r}-0.0035 \\
(4.29)\end{array}$ & $\begin{array}{r}-0.0024 \\
(3.08)\end{array}$ & $\begin{array}{r}-0.0012 \\
(1.06)\end{array}$ & $\begin{array}{r}0.0004 \\
(0.51)\end{array}$ & $\begin{array}{r}0.0001 \\
(0.11)\end{array}$ & $\begin{array}{l}-0.34 \\
(2.59)\end{array}$ \\
\hline$\alpha$ & $\begin{array}{r}0.0001 \\
(0.45)\end{array}$ & $\begin{array}{r}0.0007 \\
(1.66)\end{array}$ & $\begin{array}{r}0.0008 \\
(1.62)\end{array}$ & $\begin{array}{r}0.0006 \\
(1.59)\end{array}$ & $\begin{array}{r}0.0000 \\
(0.13)\end{array}$ & $\begin{array}{l}0.003 \\
(1.31)\end{array}$ & $\begin{array}{r}0.0074 \\
(2.31)\end{array}$ & $\begin{array}{r}0.0003 \\
(0.76)\end{array}$ \\
\hline \multicolumn{9}{|c|}{ Difference between top and bottom quintiles within diversified firms (1999-2006) } \\
\hline$R$ & 0.05 & & & & & & & \\
\hline$b$ (Market) & $\begin{array}{r}-0.0011 \\
(7.25)\end{array}$ & & & & & & & \\
\hline$s(\mathrm{SMB})$ & $\begin{array}{r}-0.0013 \\
(5.72)\end{array}$ & & & & & & & \\
\hline$h(\mathrm{HLM})$ & $\begin{array}{r}-0.0020 \\
(7.52)\end{array}$ & & & & & & & \\
\hline$\alpha$ & $\begin{array}{r}0.0004 \\
(3.69)\end{array}$ & & & & & & & \\
\hline
\end{tabular}




\section{Table IX (continued)}

Difference between top and bottom quintiles within single-segment firms (yearly)

\begin{tabular}{|c|c|c|c|c|c|c|c|c|}
\hline & 1999 & 2000 & 2001 & 2002 & 2003 & 2004 & 2005 & 2006 \\
\hline$R$ & 0.22 & 0.10 & 0.12 & 0.05 & 0.009 & 0.02 & 0.03 & 0.09 \\
\hline$b$ (Market) & $\begin{array}{r}-0.013 \\
(1.43)\end{array}$ & $\begin{array}{l}0.009 \\
(1.00)\end{array}$ & $\begin{array}{r}0.0019 \\
(3.18)\end{array}$ & $\begin{array}{r}-0.0001 \\
(0.04)\end{array}$ & $\begin{array}{r}0.0001 \\
(0.01)\end{array}$ & $\begin{array}{r}0.0003 \\
(0.58)\end{array}$ & $\begin{array}{r}0.0008 \\
(1.28)\end{array}$ & $\begin{array}{r}-0.0009 \\
(1.32)\end{array}$ \\
\hline$s(\mathrm{SMB})$ & $\begin{array}{r}-0.0037 \\
(3.28)\end{array}$ & $\begin{array}{r}-0.0031 \\
(3.35)\end{array}$ & $\begin{array}{r}-0.0012 \\
(1.20)\end{array}$ & $\begin{array}{r}-0.0008 \\
(1.04)\end{array}$ & $\begin{array}{r}0.0019 \\
(0.72)\end{array}$ & $\begin{array}{r}-0.0004 \\
(0.50)\end{array}$ & $\begin{array}{r}0.0001 \\
(0.12)\end{array}$ & $\begin{array}{r}-0.0010 \\
(1.17)\end{array}$ \\
\hline$h(\mathrm{HLM})$ & $\begin{array}{r}-0.0068 \\
(5.56)\end{array}$ & $\begin{array}{r}0.0019 \\
(1.47)\end{array}$ & $\begin{array}{r}0.0001 \\
(0.13)\end{array}$ & $\begin{array}{r}0.0013 \\
(0.11)\end{array}$ & $\begin{array}{r}-0.0056 \\
(1.14)\end{array}$ & $\begin{array}{r}-0.0026 \\
(2.44)\end{array}$ & $\begin{array}{r}-0.0024 \\
(1.95)\end{array}$ & $\begin{array}{r}-0.0057 \\
(4.29)\end{array}$ \\
\hline$\alpha$ & $\begin{array}{r}-0.0004 \\
(0.80)\end{array}$ & $\begin{array}{r}-0.0018 \\
(2.64)\end{array}$ & $\begin{array}{r}0.0009 \\
(1.68)\end{array}$ & $\begin{array}{r}-0.0019 \\
(2.41)\end{array}$ & $\begin{array}{r}-0.0002 \\
(0.19)\end{array}$ & $\begin{array}{l}0.005 \\
(1.32)\end{array}$ & $\begin{array}{l}0.001 \\
(2.74)\end{array}$ & $\begin{array}{r}0.0008 \\
(2.63)\end{array}$ \\
\hline \multicolumn{9}{|c|}{ Difference between top and bottom quintiles within single-segment firms (1999-2006) } \\
\hline$R$ & 0.04 & & & & & & & \\
\hline$b$ (Market) & $\begin{array}{r}0.0047 \\
(1.69)\end{array}$ & & & & & & & \\
\hline$s(\mathrm{SMB})$ & $\begin{array}{r}-0.0016 \\
(3.86)\end{array}$ & & & & & & & \\
\hline$h(\mathrm{HLM})$ & $\begin{array}{r}-0.0022 \\
(4.73)\end{array}$ & & & & & & & \\
\hline$\alpha$ & $\begin{array}{r}0.0008 \\
(3.44)\end{array}$ & & & & & & & \\
\hline
\end{tabular}


In Panel A, we analyse the top quintile portfolios formed by single-segment firms and diversified firms. For both single-segment and diversified firms, the yearly regression suggests high value and statistical significance in the regression coefficients and an intercept which is statistically indistinguishable from zero except for 2001 for single-segment firms and 2004 and 2005 for diversified firms, but is economically indistinguishable from zero for the entire time series. This indicates that the Fama and French model's risk factors are able to capture the difference in performance within these two classes of firms.

The value of the coefficients $b i$ and $s i$, related to the market ( $\mathrm{R} m-\mathrm{R} f$ ) and the size (SMB) premiums, respectively, are higher and statistically significant within single-segment firms. Over the entire time series 1999-2006, investors ask for higher returns from single-segment firms in relation to a) their market volatility, and b) their smaller size compared with diversified firms. On the other hand, the value of the coefficient $h$ related to the value premium (HML) is higher and statistically significant within diversified firms. Over the entire time series 1999- 2006, investors ask for higher returns from diversified firms because they are considered "value stock," given their relatively higher BE/ME ratio in comparison with single-segment firms. We obtain similar results when we regress the difference $(\Delta \mathrm{R} p)$ between single-segment and diversified firms.

In Panel B, we analyse the bottom quintile portfolios formed by single-segment and diversified firms. When we analyse the coefficient related to all three factors, we find similar results as in Panel A, except for the intercept, which is statistically not indistinguishable from zero even though it is economically not significant. This indicates that the risk factors of the Fama and French model are able to capture some of the difference in performance within these two classes of firms but something remains unexplained.

When we regress the portfolios' return difference $(\Delta \mathrm{R} p)$, we obtain confirmation of the result found in panel A for the difference in the top quintile. However, for the bottom quintile, the Fama and French model shows a low correlation $R^{2}{ }_{\text {Adj }}$, most likely because of the high scatter, which gives a different interpretation to the results of this specific regression. In Panel $C$, we regress the difference between the top and bottom quintiles of single-segment and diversified firms $(\Delta \mathrm{R} p)$ with respect to the Fama and French model. The correlation coefficient $R^{2}{ }_{\text {Adj }}$ obtained is not very representative. The regression coefficients in Panels A and B of the top and bottom quintiles (both single-segment and diversified firms) show a consistent, statistically significant difference: the top quintile shows a consistently lower risk, lower size and lower value premium when we regress the portfolio's returns with respect to the Fama and French model.

We conclude from the regression of the portfolio's returns with respect to Fama and French's assets pricing model that investors in single-segment firms ask for higher market and size premiums but a lower value premium, while investors in diversified firms ask for lower market and size premiums but a higher value premium. Over the entire time series 1999-2006, investors ask for higher returns from diversified firms because they are considered to be "value stock," given their relatively higher BE/ME ratio compared with single-segment firms. Finally, when we compare the coefficient between top and bottom quintiles within single-segment and diversified firms, respectively, we can state from Panel A that the top quintiles have a lower coefficient value related to the risk factors. The Fama and French three-factor model also confirms the persistence of outstanding performance found previously. 


\section{Risk measurement: conditional variance and conditional covariance}

Previous findings have shown that once the empirical evidence of the persistence of abnormal return is taken into consideration, the widely held concept that, "on average," diversified firms destroy value is not confirmed. Moreover, when the Fama and French assets pricing model is applied, we find that an important part of the difference in return between single-segment and diversified firms is explained by the three Fama and French risk factors: the market factor, the size factor and the value factor. We go further in this direction in order to find other factors that might explain the difference in return between single-segment and diversified firms. Here, we analyse more carefully the risk related to the top and bottom quintile portfolios. From Table X, the descriptive statistics of the portfolio return distributions, we see that the daily unconditional volatility is lower within the portfolios of diversified firms: for the top quintiles, we have a coefficient $\sigma$ of 0.0091compared with 0.012, and for the bottom quintiles, we have a coefficient $\sigma$ of 0.010 compared with 0.014. These results assume that the returns follow a normal distribution but, as we can see, this is not the case. As can be seen form the distribution parameters and the return distribution histogram (Figure 1), the returns do not follow a normal distribution: all distributions have a fat tail (kurtosis higher than 3) and, except for the bottom quintile of diversified firms (negatively skewed), the other portfolios are positively skewed instead of 0 . As expected, top quintiles have higher average returns than bottom quintiles, given the empirical evidence of the persistence of outstanding performance.

\section{Table X}

Distribution and basic statistics of returns

The table shows the mean, standard deviation, skewness, kurtosis, maximum and minimum of the daily returns for the top and bottom quintile portfolios of single-segment and diversified firms. We can see that the distribution of returns is not normal for all cases: a normal distribution implies zero skewness (symmetric distribution) and kurtosis equal to 3 (normal peakiness, not fat tails).

Distribution of portfolio returns:

\begin{tabular}{|l|r|r|r|r|}
\hline Statistic & $\begin{array}{l}\text { Single-segment } \\
\text { firms } \\
\text { Top Quintile }\end{array}$ & $\begin{array}{l}\text { Single-segment } \\
\text { firms } \\
\text { Bottom Quintile }\end{array}$ & $\begin{array}{l}\text { Diversified firms } \\
\text { Top Quintile }\end{array}$ & $\begin{array}{l}\text { Diversified firms } \\
\text { Bottom Quintile }\end{array}$ \\
\hline$\mu$ & 0.0006182 & -0.0002478 & 0.0006211 & -0.0000234 \\
\hline$\sigma$ & 0.01202 & 0.0142569 & 0.0091273 & 0.0104531 \\
\hline Skewness & 0.0421655 & 0.000356 & 0.0061088 & -0.1537581 \\
\hline Kurtosis & 5.642445 & 105.1802 & 4.177992 & 4.83263 \\
\hline Max. & 0.0632829 & 0.2616302 & 0.0428319 & 0.0522806 \\
\hline Min. & -0.0881613 & -0.2495758 & -0.0430556 & -0.057147 \\
\hline
\end{tabular}




\section{Figure 1}

Distribution of returns of top and bottom quintiles
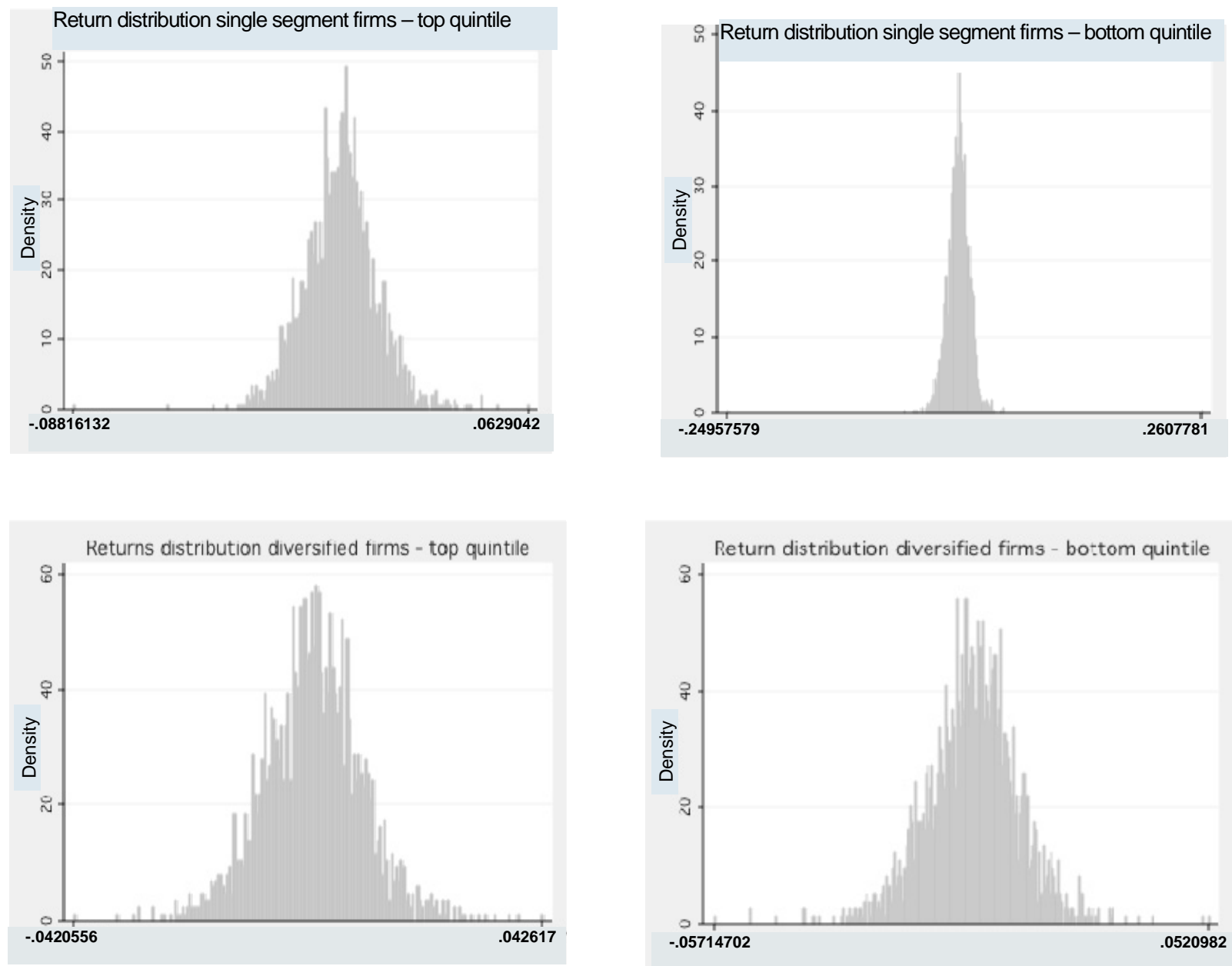

\section{Conditional variance using the NGARCH $(1,1)$ model}

Because of the non-normality of the return distribution, we cannot estimate the risk related to the portfolios through the daily unconditional variance $\sigma$. We need to estimate the daily conditional variance. We also estimate the daily conditional covariance (the dynamic beta) with respect to the Standard \& Poor 500 market index (the same reference market used to calculate Jensen's alpha).

The NGARCH $(1,1)$ model describes the dynamic behavior of the conditional variance, following the formula:

$$
\sigma_{t}^{2}=\omega+\alpha\left(R_{t-1}-\theta \sigma_{t-1}\right)^{2}+\beta \sigma_{t-1}^{2}
$$

in which $w$ is the long-term variance $\gamma V_{L}$ (a sort of unconditional variance), $\gamma$ is the weight assigned to the long-term variance, $\alpha$ is the weight of the volatility related to the innovations of latest news at day $t-1$, and $\beta$ is a weight of the previously estimated conditional variance of the persistence of volatility, with the condition that $\gamma+\alpha+\beta=1$. The parameter $\theta$ is the 
asymmetric parameter given that negative returns due to bad news increase the variance rate more than positive returns of the same magnitude. This is also known as the "leverage effect," since a decrease in the asset's price reduces the company's market value relative to the debt's market value, and therefore the debt/equity ratio also increases.

Table XI and Figure 2 show the results. It can be seen that the daily volatility within singlesegment firms (both top and bottom quintiles) is mainly explained by the long-term volatility part of the equation $\gamma V_{L}(w)$, and especially by the parameter $\gamma$, which is 0.871 and 0.662 within single-segment firms compared with 0.003 and 0.0254 within diversified firms, but also by the long-term volatility $\sigma_{\mathrm{L}}$ which is 0.0163 and 0.018 respectively within single-segment firms compared with 0.013 and 0.0088 within diversified firms. These figures are confirmed by the value of the parameter $\beta$, which measures the persistence of the volatility $\sigma_{\mathrm{t}-1}: 2.008 \mathrm{E}-08$ and almost 0 within single-segment firms compared with 0.924 and 0.885 within diversified firms, although the volatility of single-segment firms reacts to a greater degree to the news at t-1 with a coefficient $\alpha$ of 0.12 and 0.33 compared with 0.048 and 0.031 for diversified firms. The value of the persistence of volatility at $t-1$ according to the formula $[\alpha(1+\theta)+\beta]$ single-segment firms (0.12 and 0.33) and much higher for diversified firms (0.996 and 0.0947). Finally, we find that single-segment firms have a lower "leverage effect" than diversified firms, supposedly because of the negative value of the skewness, while the bottom quintile of diversified firms shows the highest "leverage effects." As supposed, we find a negative sign for the correlation $\rho$ between news and conditional variance. Finally, we confirm that within each group of diversified and single-segment firms, the top quintile has less volatility than the bottom quintile.

When we look at the graph, we see that, during the entire time series 1999-2006, singlesegment firms have higher volatility than diversified firms. This is especially evident when we compare the conditional volatility between top quintiles and between bottom quintiles. To conclude, single-segment firms have a significantly higher volatility; this volatility is mainly explained by a long-term volatility or "sticky" or structural volatility and reacts to a greater degree to the latest news and market news than diversified firms. 


\section{Table XI}

Parameters of the daily conditional variance model NGARCH $(1,1)$

The NGARCH $(1,1)$ model describes the dynamic behavior of the conditional variance, determining its value at each specific time as a function of its value one day before, the value of the (squared) innovations one day before, the long-term average variance and the "leverage effect." The latter effect is explained by the fact that negative returns due to the arrival of bad news increase the variance rate more than positive returns of the same magnitude.

The formula of the conditional variance is:

$$
\sigma_{t}^{2}=\omega+\alpha\left(R_{t-1}-\theta \sigma_{t-1}\right)^{2}+\beta \sigma_{t-1}^{2}
$$

The term $(1,1)$ indicates that the conditional variance is based on the most recent observation of the squared return, and the most recent estimate of the variance rate (both lags $=1$ ). This asymmetric NGARCH specification assigns weights to the (squared) returns depending on whether the return is negative or positive. Thus, it incorporates the previously mentioned asymmetric effect. The approach used is again the maximum-likelihood method, which implies selecting values for the parameters that maximize the chance (or likelihood) of the data occurring using the following formula: $\sum_{i=1}^{n}\left[-1 n\left(v_{i}\right)-\frac{R_{i}^{2}}{v_{i}}\right]$, where $v_{i}$ is the daily variance, and $\mathrm{R}_{\mathrm{i}}^{2}$ is the daily observation $\left(\mathrm{R}_{\mathrm{i}^{-}} \bar{R}\right)^{2}$ or the daily square of the innovation of return. For the first observation of the conditional variance, we used the unconditional variance of the sample's returns. In all cases $\alpha+\beta<1$; this is required for a stable NGARCH $(1,1)$. Otherwise, the weight assigned to $\mathrm{V}_{\mathrm{L}}$ would be negative and the process would be mean fleeing rather than mean reverting.

\begin{tabular}{|l|l|r|r|r|r|}
\hline \multicolumn{2}{|l|}{ NGARCH (1,1) } & $\begin{array}{c}\text { Single-segment } \\
\text { Top Quintile }\end{array}$ & $\begin{array}{c}\text { Single-segment } \\
\text { Bottom Quintile }\end{array}$ & \multicolumn{1}{c|}{$\begin{array}{c}\text { Diversified } \\
\text { Top Quintile }\end{array}$} & \multicolumn{1}{c|}{$\begin{array}{c}\text { Diversified } \\
\text { Bottom Quintile }\end{array}$} \\
\hline \multirow{3}{*}{$\begin{array}{l}\text { Parameter } \\
\text { estimates }\end{array}$} & $\mathrm{W}$ & 0.000233698 & 0.000236209 & $6.59938 \mathrm{E}-07$ & $1,97962 \mathrm{E}-06$ \\
\cline { 2 - 6 } & $\alpha$ & 0.123194519 & 0.334646615 & 0.048231232 & 0,031227521 \\
\cline { 2 - 6 } & $\beta$ & $2.00893 \mathrm{E}-08$ & 0.00000001 & 0.924727671 & 0,885953901 \\
\cline { 2 - 6 } & $\theta$ & 0.215959224 & 0.089951788 & 0.694384884 & 1,35496899 \\
\hline $\mathrm{V}$ & 0,87105987 & 0.66264564 & 0.00378543 & 0.02548669 \\
\hline$V_{\mathrm{L}}$ & 0,000268292 & 0.000356463 & 0.000174337 & 0.000076727 \\
\hline$\sigma \mathrm{L}$ & 0,016379621 & 0.018880235 & 0.01320366 & 0.008813214 \\
\hline$\rho$ & $-0,62854419$ & -0.42075958 & -0.840827129 & -0.76161194 \\
\hline \multicolumn{2}{l|l}{ Persistence $\left(\sigma_{\mathrm{t}-1}\right)$} & 0,12894013 & 0.33735436 & 0.99621457 & 0.97451331 \\
\hline
\end{tabular}




\section{Figure 2}

Daily conditional volatility according to the $\operatorname{NGARCH}(1,1)$ model

Single-segment firms
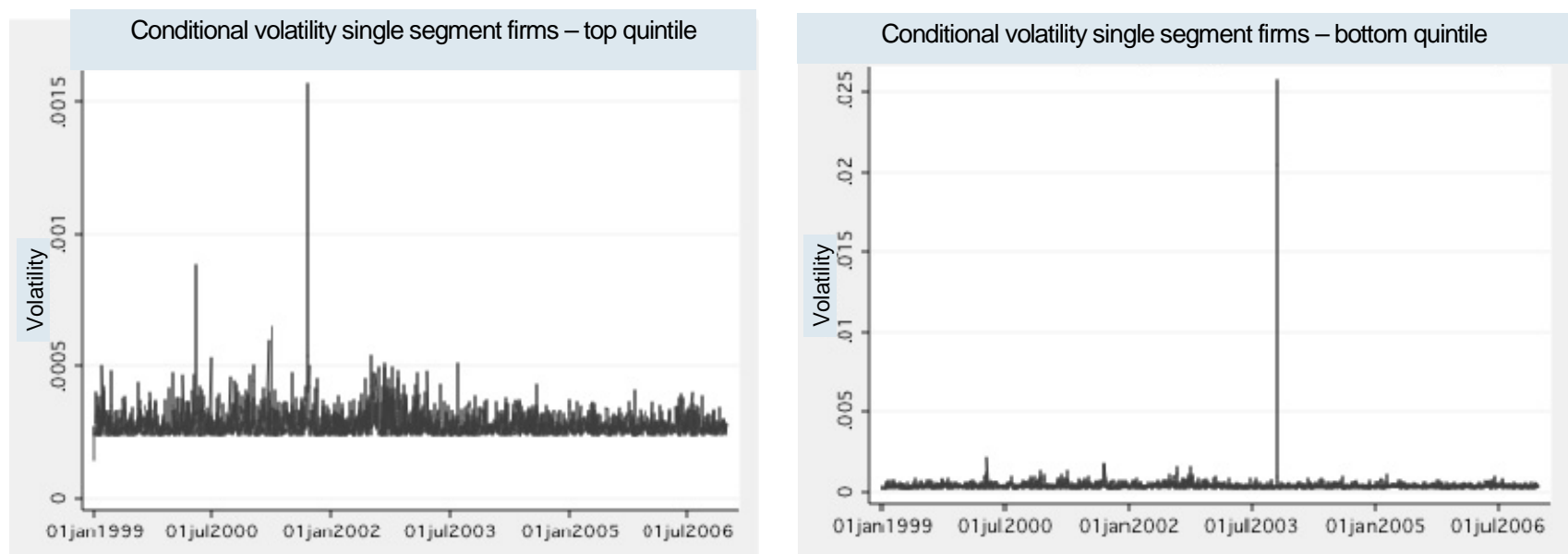

\section{Diversified firms}
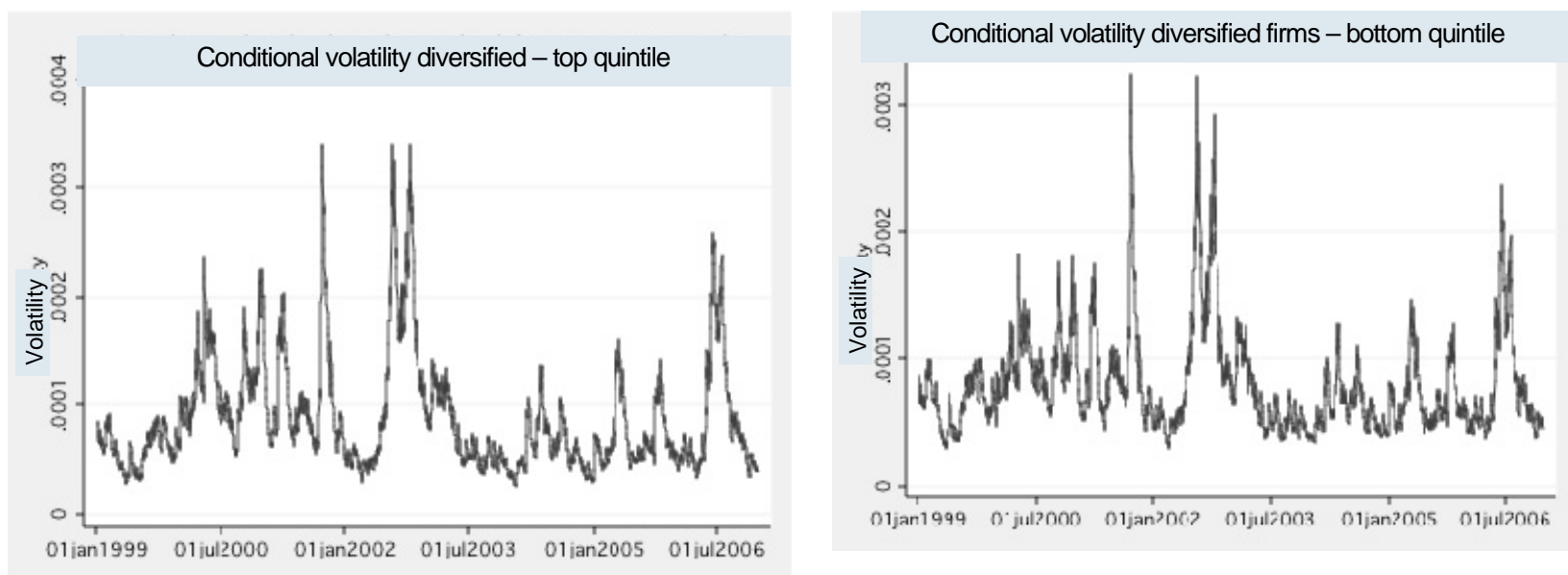

Difference between single-segment firms and diversified firms
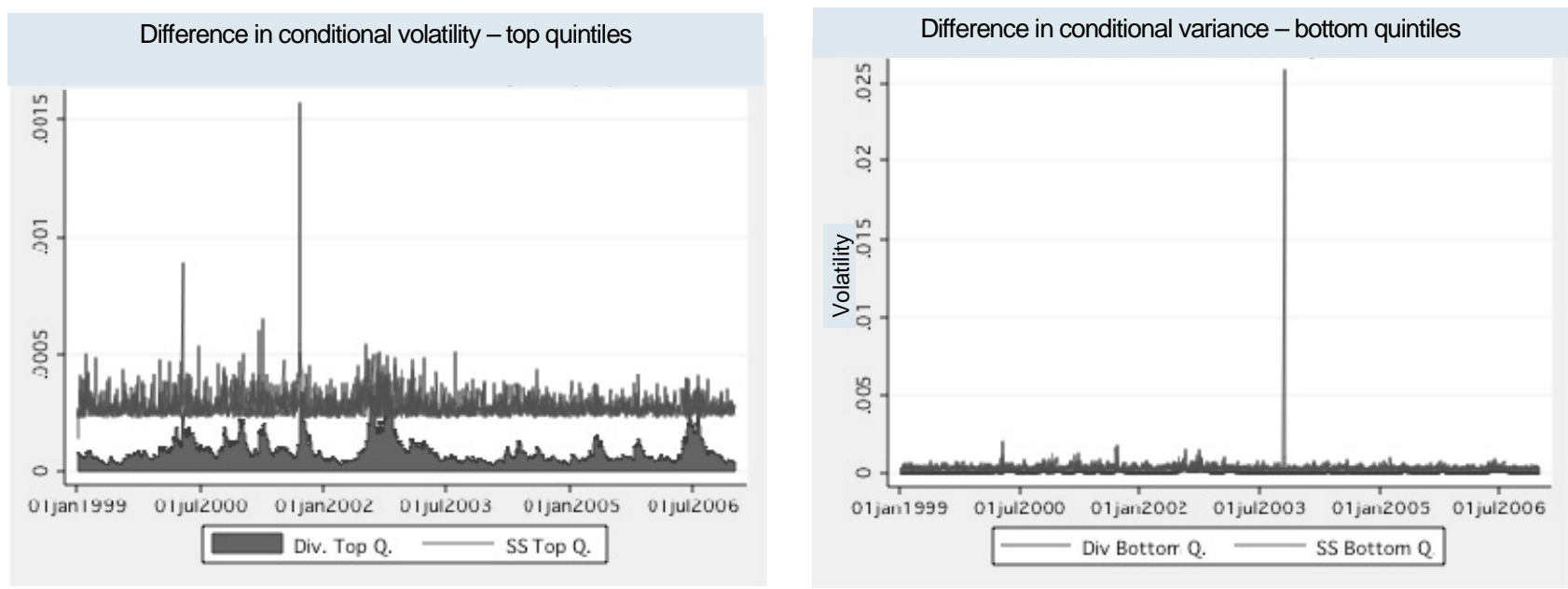


\section{Conditional covariance using the GARCH $(1,1)$ model}

We also use the GARCH $(1,1)$ model to estimate the conditional covariance $(\beta)$ between the top and bottom quintiles (both single-segment and diversified firms) with the S\&P 500 index as well as the variance of each portfolio in order to estimate the conditional $\beta$.

The conditional covariance is estimated with the formula:

$$
\operatorname{Cov}_{t}=\omega+\alpha\left(R 1_{t-1}-R 2_{t-1}\right)+\beta \operatorname{Cov}_{t-1}
$$

The conditional variance of each portfolio is estimated with the formula:

$$
\sigma_{t}^{2}=\gamma V_{L}+\alpha R_{t-1}^{2}+\beta \sigma_{t-1}^{2}
$$

Finally the conditional $\beta$ is estimated through the formula:

$$
\beta=\operatorname{Cov}_{t} / \sigma_{t}^{2}
$$

Figure 3 shows the results. We notice that the top quintiles, whose conditional $\beta$ ranges from 0.5 to 1.5 , have a lower conditional $\beta$ than bottom quintiles, whose $\beta$ ranges from 0.5 to 2 . When we compare single-segment firms with diversified firms, we see for top quintiles that single-segment firms have a higher conditional covariance than diversified firms, especially during the time series between 1999-2003. A similar but less marked pattern is found among bottom quintiles.

\section{Figure 3}

\section{Conditional covariance using $\mathrm{GARCH}(1,1)$}

We also use the GARCH $(1,1)$ model to estimate the conditional covariance between the top and bottom quintiles (both single-segment and diversified firms) using the S\&P 500 index to estimate the conditional beta.

The conditional covariance is: $\operatorname{Cov}_{t}=w+\alpha\left(R_{1(t-1)}-R_{2(t-1)}\right)+\beta \operatorname{Cov}_{t-1}$ where $\alpha$ is the coefficient related to the shock effect (or effect on innovation) $\beta$ is the coefficient related to covariance persistence between the portfolio and the S\&P 500 index, and with the long-term covariance according the following formula: $\omega /(1-\alpha-\beta)$. The maximum likelihood method is used to estimate the conditional beta. This implies selecting values for the parameters that maximize the chance (or likelihood) of the data occurring according to the following formula:

$$
\sum_{t=1}^{T}\left[-\ln \left(1-\rho_{1,2 t}^{2}\right)-\frac{\left(R_{1 t}^{2}+R_{2 t}^{2}-2 \rho_{1,2} R_{1 t} R_{2 t}\right)}{\left(1-\rho_{1,2 t}^{2}\right)}\right]
$$

where $\mathrm{R}_{\mathrm{i}}^{2}$ is the daily observation $\left(\mathrm{R}_{\mathrm{i}}-\bar{R}\right)^{2}$ or the daily square of the innovation of return, and $\rho^{2}{ }_{1,2 t}$ is the square of the correlation coefficient between innovations obtained by determining the daily covariance between the portfolio and the S\&P 500 index from the product of the daily variance of the portfolio and the S\&P 500 given by the GARCH $(1,1)$ model. 
The graphs below show the daily beta for each portfolio as well as the difference in the daily beta between top and bottom quintiles. The unconditional beta is the ratio $\beta=\operatorname{Cov}_{t} / \sigma_{t}^{2}$.
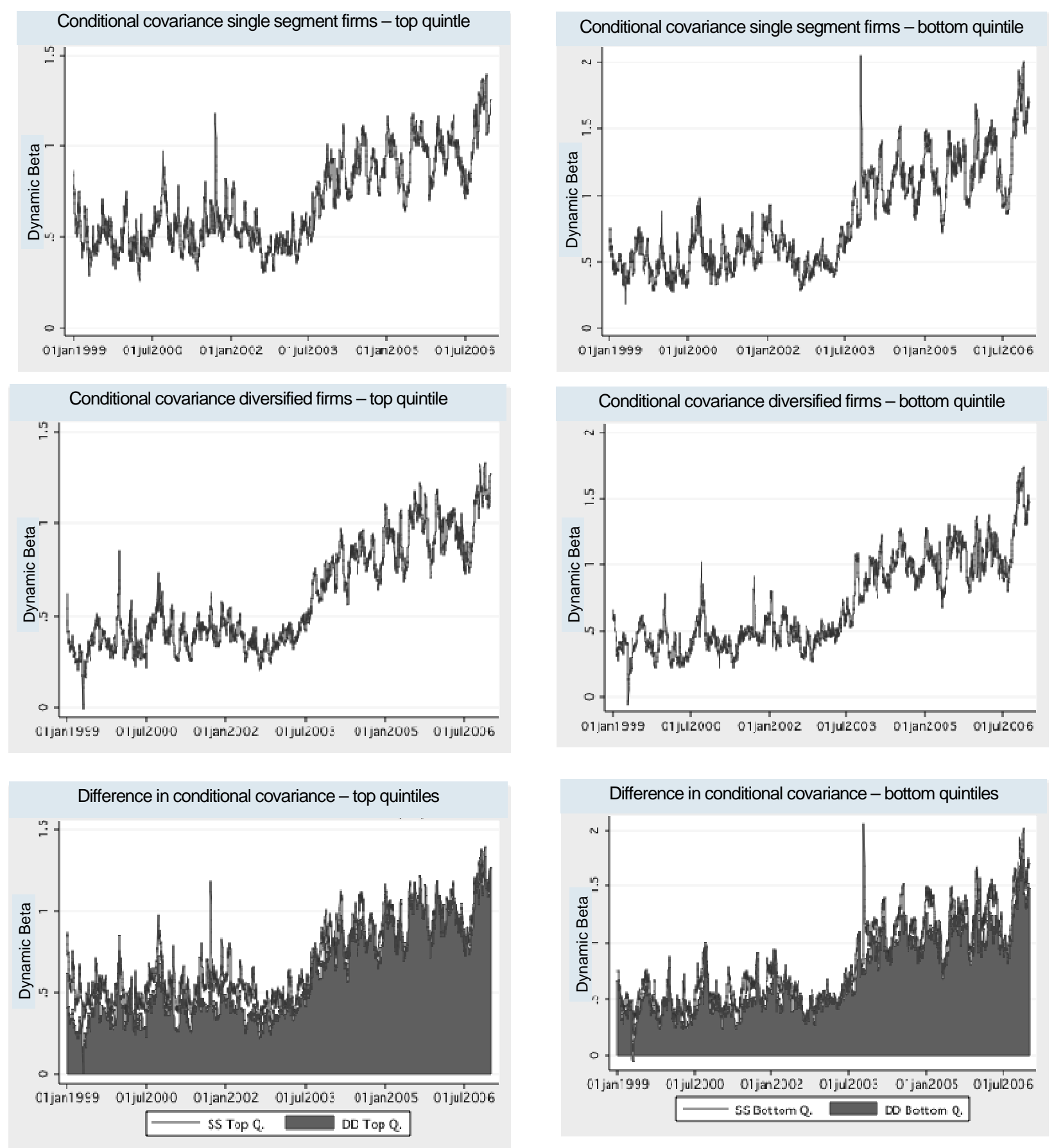


\section{Conclusion and Direction for Future Research}

Based on the empirical evidence in industrial organisation economics and strategic management literature concerning the persistence of outstanding performance, we offer new insights and an additional view of the relationship between shareholder value and diversification. We do not find that single-segment firms generate more shareholder value than diversified firms. Moreover, when we analyse the group of bottom performers, the opposite is true: diversified firms generate higher shareholder value than single-segment firms. Investors in single-segment firms expect an additional return related to their smaller size, while investors in diversified firms expect an additional return because they view these diversified firms as "value stocks" in comparison with single-segment firms. In addition, when we compare the volatility of single-segment and diversified firms, we clearly find that single-segment firms are much more volatile. Their daily volatility is mainly explained by their long-term or "sticky volatility" and reacts more strongly to the latest news than diversified firms. We do not attempt to answer the classical research questions in finance of whether a business segment is better off within a diversified firm or whether, "on average," single-segment firms create more value than diversified firms. Instead, we measure shareholder value and other characteristics based on the empirical finding of a substantial persistence of outstanding performance, we confirm that from an investor's perspective, diversified firms are able to create shareholder value and beat the market index with lower volatility. Hence, we do not find any argument in favour of a diversification discount.

The results of this research indicate that the relationship between diversification and shareholder value is not causal, but rather that it clearly depends on the firm's capacity to generate a long-term persistence of outstanding performance. Future research should be oriented towards developing additional indicators both at management and diversification strategy levels in order to test what portion of the explanation of the outstanding performance pattern of diversified firms resides within the firm's strategy and management capabilities. 


\section{References}

Anderson T.W. and C. Hsiao (1981), "Estimation of dynamic model with error components," Journal of the American Statistical Association, pp. 589-606.

Arellano, M. (2003), "Panel data econometrics,” Oxford University Press.

Berg, G.B. and E. Ofek (1995), "Diversification Effects on Firm Value," Journal of Financial Economics, pp. 37: 39-65.

Berger P.G. and R. Hann (2003). "The impact of SFAS N0 131 on information and monitoring," Journal of Accounting Research, 41, pp. 163-223.

Bentzen, J., E. Strojer Madsen, S. Valdemart, and M. Dilling-Hansen (2005), "Persistence of corporate performance? Empirical evidence from panel unit root test," Empirica, 32, pp. 217-230.

Billet, M. and D. Mauer (2003), "Cross-subsidies, external financing constraints and the contribution of the internal capital market," Review of Financial Studies, 16, pp. 1167-1202.

Bond, S.R. (2002)," Dynamic panel data models: a guide to micro data methods and practice," Portuguese Economic Journal 1, pp. 141-162.

Campa, J.M. and R. Kedia (2002), "Explaining the diversification discount," Journal of Finance, 57(4), pp. 1731-1762.

Campello, M. (2002), "Internal capital market in financial conglomerates: evidence from small bank response to monetary policy,” Journal of Finance, 57(6), pp. 2773-2805.

Denis, D.D., D.K. Denis and A. Sarin (1997), “Agency problems, equity ownership, and corporate diversification,” The Journal of Finance, 52(1), pp. 111-133.

Fama, E.F. and K.R. French (1992), "The cross-section of expected stock return," Journal of Finance, 47(2), pp. 427-465.

Fama, E.F. and K.R. French (1993), "Common risk factors in the returns on stocks and bonds," Journal of Financial Economics, 33 pp. 3-56.

Fama, E.F. and K.R. French (1995), "Size and book-to-market factors in earnings and returns.," Journal of Finance, 50(1), pp. 131-156.

Gertner, R.H., D.S. Scharfstein, and J.C. Stein (1994), "Internal versus external capital markets, “The Quarterly Journal of Economics, 59, pp. 1211-1230.

Graham, J.R., M.L. Lemmon, and R. Wolf R. (2002), "Does corporate diversification destroy value?," Journal of Finance, 57(2), pp. 695-720.

Guedji, I. and D. Sharfstein (2004), "Organisational scope and investment: evidence from the drug development strategies and performance, "Working paper, NBER number 10933.

Hyland, D.C. and D.J. Diltz (2002), "Why firms diversify: an empirical examination, "Financial Management, pp. 51-81.

Jacobsen, R. (1988), "The Persistence of abnormal return, "Strategic Management Journal, (9) pp. 415-430. 
Jensen, M.C. (1969), "Risk, the pricing of capital assets, and the evaluation of investment portfolios," The Journal of Business, 42(2), pp. 167-247.

Jensen, M.C. (1986), "Agency cost of free cash flow, corporate finance and takeovers," American Economic Review Papers and Proceedings, 76, pp. 323-329.

Kaplan, S.N. and A. Schoar (2005), "Private equity performance: returns, persistence and capital flows,” Journal of Finance, 60 (4), pp. 1791-1823.

Keiser, K.M.J. and A. Stouraitis (2001), "Reversing corporate diversification and the use of the proceeds from asset sales: The Case of Thorn EMI," Financial Management, pp. 5-44.

Khanna, N. and S. Tice (2001), "The bright side of internal capital markets," Journal of Finance, 56(4), pp. 1489-1528.

Lamont, O.A. and C. Polik (2001), "The diversification discount: cash flows versus returns," The Journal of Finance, 56(5), pp. 1693-1721.

Lang, L.H.P. and R.M. Stulz (1994), “Tobin's q, corporate diversification, and firm performance," Journal of Political Economics, 102 (6), pp. 1248-1280.

Maksimovic, V. and G. Phillips (2002), "Do conglomerate firms allocate resources inefficiently across industries? Theory and evidence," Journal of Finance, 57 (2), pp. 721-767.

Maksimovic, V. and G. Phillips (2006), "Conglomerate firms and internal capital markets," forthcoming, Handbook of Corporate Finance, Elsevier / North Holland.

Mansi, S.A. and D.M. Reeb (2002), “Corporate diversification: what gets discounted?," Journal of Finance, 57(5), pp. 2167-2183.

Marinelli, F. (2008), "Persistence of outstanding performance and shareholder value among diversified firms: the impact of past performance, internal capital market, and relatedness of business segments," IESE Working Paper WP-758.

Martin, J.D. and A. Sayrak (2003), "Corporate diversification and shareholders value: a survey of recent literature,” Journal of Corporate Finance, 9 (1), pp. 37-57.

Maruyama, N. and H. Odagiri (2002), "Does the persistence of profit persist? A study of company profit in Japan," International Journal of Industrial Organization, 20(10), pp. 1513- 1533.

McGahan A., and M.E. Porter (1999), "The persistence of shocks to profitability," The Review of Economics and Statistics, 81(1), pp. 143-153.

McGahan, A. and M.E. Porter (2003), "The emergence and sustainability of abnormal profit," Strategic Organization, 1(1), pp. 79-108.

Mueller, D.C. (1977), “The persistence of profit above the norm,” Economica, 44, pp. 369-380.

Peyer, U. (2001), “Internal and external capital markets," Working paper, University of North Carolina at Chapel Hill.

Rajan, R., H. Servaes, and L. Zingales (2000), "The cost of diversity: the diversification discount and inefficient investment," Journal of Finance, 55(1), pp. 35-80. 
Santalo, J. and M. Becerra M. (2008), "Competition from specialized firms and the diversification-performance linkage," Journal of Finance 63(2), pp. 852-883.

Scharfstein, D.S., and J.C. Stein (2002), “The dark side of the internal capital markets: Divisional rent-seeking and inefficient investment”, Journal of Finance, 55(6), pp. 2537-2564.

Schohl, F. (1990), "The persistence of profit in the long run - a critical extension of some recent findings," International Journal of Industrial Organization. 8(3), pp. 385-404.

Schoar, A. (2002), "Effects of corporate diversification on productivity," Journal of Finance, 57(6), pp. 2379-2403.

Shin, H.H. and R.M. Stulz (1998), "Are internal capital market efficient?,” The Quarterly Journal of Economics, 113, pp. 531-552.

Sharpe, W.F. (1964), "Capital asset prices: A theory of market equilibrium under condition of risk,” Journal of Finance, 19(3), pp. 425-442.

Stein, J.C. (1997), “Internal capital market and the competition for corporate resources," Journal of Finance, 52(1), pp. 111-133.

Stowe, J.D. and X. Xing (2006), "Can growth opportunities explain the diversification discount?,” Journal of Corporate Finance, 12(4), pp. 783-786.

Villalonga, B. (2004a), "Diversification discount or premium? New evidence from the business information tracking series," Journal of Finance, 59(4), pp. 475-502.

Villalonga, B. (2004b), "Does diversification cause the diversification discount?," Financial Management, 33(2), pp. 5-27.

Waring, G.F. (1996), "Industry differences in the persistence of firm-specific returns," American Economic Review, 86(5), pp. 1253-1265.

Wernerfelt, B. and C. Montgomery C. (1988), "Tobin's q and the importance of focus in firm performance," American Economic Review, 78(1), pp. 246-250.

White, T.M. (2001), "Is it inefficient investment that causes the diversification discount?," Journal of Finance, 56(5), pp. 1667-1691.

Wiggins, R.R. and T.W. Ruefli (2002), "Sustained competitive advantage: temporal dynamics and the incidence and persistence of superior economic performance,” Organization Science, 1(13), pp. 81-105.

Wiggins, R. R. and T.W. Ruefli (2005), "Schumpeter's ghost: is hypercompetition making the best of times shorter?,” Strategic Management Journal, 26(10), pp. 887-991.

Williamson, 0.E. (1975), "Markets and Hierarchies, Analysis and Antitrust Implications," The Free Press, New York.

Williamson, O.E. (1985), “The Economic Institutions of Capitalism,” The Free Press, New York.

Yurtoglu, B.B. (2004), "Persistence of firm-level profitability in Turkey," Applied Economics, 36(6), pp. 615-625. 